\section{一 般口演}

A-1-1. 上下顎移動術を行った顔面非対称症例のチーム アプローチ I

一骨格形態の変化一

北海道大学大学院歯学研究科口腔機能学講座

歯科矯正学分野

○高木 洋美, 豊 泉 裕, 山本 隆昭, 山方 秀一, 佐藤 嘉晃, 山崎 篤, 飯田順一郎

【目的】顔面非対称を伴う顎変形症症例で咬合平面の左右的傾斜 を有する場合, その改善を目的として上下顎移動術を適用するこ とがある。今回, このような症例について, 術前後の骨格形態の 変化を検討したので報告する。

【研究対象】本院で上下顎移動術を適用し, 術後 1 年以上経過し, 動的治療を終了した患者 8 名（男性 1 名，女性 7 名）を用いた。 内訳は，骨格性反対咬合が 5 例，骨格性交叉咬合が 3 例であった。 【研究方法】資料には術直前 ( $\mathrm{T} 1)$, 術直後 ( $\mathrm{T} 2)$, 術後 6 か月 (T3), 術後 1 年 (T4) における正面頭部 X 線規格写真を用い, 左右 Lo，Lo’を結ぶ直線を基準線とした。（1）設定した正中線 からオトガイ棘までの距離（偏位側にある場合を正)，（2）基準 線と上顎左右大臼歯煩側歯頸部点（Mo, Mo'）を結ぶ直線との なす角（ $\angle \mathrm{Mo}-\mathrm{Mo}$ ：偏位側上がりの傾斜の場合を正）を求めた。 （3）正中線から Mo, Mo’およびGo, Go’までの距離を計測し, それぞれの Asymmetry Indexを算出した。

【結果】オトガイ棘について, T1 で+4.5〜 +11.0mm, T2 で $-2.0 \sim+2.0 \mathrm{~mm}, \mathrm{~T} 3$ で$-1.0 \sim+2.5 \mathrm{~mm}, \mathrm{~T} 4$ で $-1.0 \sim+3.0$ $\mathrm{mm}$ であった。 $\angle \mathrm{Mo}-\mathrm{Mo}$ 'は, T1 1 では 6 例で+4.0〜 +8. $0^{\circ}, 2$

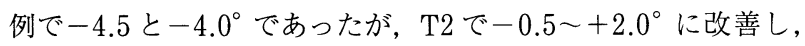
T3，T4においても T2 とほほ同じ值となっていた。Mo，Mo’ の Asymmetry Index (平均值) は, $\mathrm{T} 1$ で $4.6 \%, \mathrm{~T} 2, \mathrm{~T} 3, \mathrm{~T} 4$ で $2.0 \%$ 以下であったのに対し, Go, Goの Asymmetry Index (平均值) は $\mathrm{T} 1$ で $6.5 \%, \mathrm{~T} 2$ で $1.6 \%, \mathrm{~T} 3$ で $2.2 \%, \mathrm{~T} 4$ で $2.6 \%$ であった。

以上より, 術後のオトガイの偏位，上顎骨の傾斜および左右の 対称性はほほ改善され, 術後 1 年までの上下顎骨の位置はほぼ安 定していたと考えられる。

質問岡山大 · 大学院 - 歯顎口腔病態外科 西山 明慶 1. オクルーザルカントに扔ける手術適応のクライテリアはど の様にされていますか。

2. Goの位置変化において近位骨片の後位方法や骨接合法の 影響はありませんか。
1. 矯正治療のみと手術適応の border case では, それぞれ の set up model を作成し, 患者さんの要望（どこまで治したい のか，手術の希望はあるのか）に合わせて治療方針を決定してい ます。しかし顎関係や咬合の状態が border case でも歯根の吸 収や軟組織の影響で矯正治療単独では治せない場合, 歯牙に悪影 響を与える場合は手術適応としています。

2. Goの位置変化により咀嚼筋および下顎骨の形態の影響が あるため, 後戻りを考慮した多めの移動や接合部の接触面積を大 きめにとるようにしております。

質問 佐賀医大 ·医 ·歯口外 後藤 昌昭

P-A セファロでどの程度下顎の動きが把握できるものでしょう 加。

回答 北海道大 · 大学院 ·歯矯正 高木 洋美

P-Aセファロでは 2 次元的な動き（上下左右）の把握に限られ ますので，下顎の動きを詳細に把握するためには BASIS CT な どを用いて下顎の前後左右的移動および回転を考慮した 3 次元的 な評価が必要であると思います。

\section{A-1-2. 上下顎移動術を行った顔面非対称症例のチーム アプローチ II 一咬合の安定性一 \\ 北海道大学大学院歯学研究科口腔機能学講座 \\ ○請川 哲也, 笠井 信行, 二宮 隆明, 大畑昇 \\ 北海道大学歯学部附属病院保存系歯科 奥田 耕一, 高 道 理}

【目的】北海道大学歯学部附属病院では, 顎変形症に対する治療 において, 治療後に個々の症例にとって最も機能的に安定した咬 合 Desirable Occlusion（D.O.）を得ることを目標としている。 そこで初診時から口腔外科・矯正科・補緅科のチームアプローチ により一貫した治療を行っている。上下顎移動術を行った症例に おいては上顎咬合平面の左右的傾斜を改善し, 術後の後戻りを極 力防止するうえで, D.O. 設定時の咬合関係においては, 特に前 歯部の被蓋関係や臼歯部の咬合状態が重要であると思われる。そ こで顔面非対称症例に対して, 咬合改善を目的に上下顎移動術を 行った症例について, 術前・術後の咬合の安定性の比較検討を行っ たので報告する。【対象・方法】顔面非対称症例に対し上下顎移 動術を行った患者 13 名について, 検討を行った。半調節性咬合 器上で行った D.O. 設定時（術前）と術後の動的矯正終了後（術 後）の咬合状態について, 模型上での咬合接触状態, 顎運動記録 装置（シロナソグラフ）での下顎中切歯の限界運動路, 咬合力測 定システム（デンタルプレスケール）での咬合接触圧と咬合接触 部位を調べ, 術前・術後の咬合の安定性を比較検討した。【結 果】術後では, 中心咬合位での咬合接触部位の増加が認められ, 側方歯群の押さえ込みも獲得されており，咬合の安定性が得られ ていた。下顎中切歯の限界運動路においても術後に改善傾向が認 められた。 
質問 中央矯正歯科クリニック 鈴木 純一

術前・術後の咀嚼側に関し, 変化があったのか否か。

回答 北海道大 . 大学院 - 口腔機能 請川 哲也

咀嚼側や咀嚼能率の変化も含めてこれからの検討課題とさせて 頂きます。

\section{A-1-3. 上下顎移動術を行った顔面非対称症例のチーム アプローチ III 一顔貌の変化一}

北海道大学大学院歯学研究科口腔健康科学講座 高齢者口腔健康管理学分野

○柏崎 晴彦，井上農夫男

北海道大学大学院歯学研究科口腔病態学講座 口腔顎顔面外科学分野

山口 博雄, 尾田 充孝, 大賀 則孝,

松沢 正宏, 鹿内 秀高, 越川 高光,

戸塚 靖則

【目的】北海道大学歯学部附属病院では, 顎変形症に対し, 安定 した機能的咬合，すなわち desirable occlusion（D.O.）を得 ることを第一の目的として, 口腔外科・矯正科・補緅科の 3 科の チームアプローチによる一貫した治療を行っている。今回，上下 顎移動術を行った顔面非対称症例について術前・術後の顔貌の変 化について検討した。【対象と方法】咬合改善を目的に上下顎移 動術を行った顔面非対称症例のうち, 術後 1 年以上経過した 10 名（男性 1 名，女性 9 名，平均年齢 27.1 歳）を対象とした。術 式はいずれも Le Fort I 型骨切り術十下顎枝矢状分割術であっ た。内訳は，骨格性反対咬合 4 名，骨格性反対咬合十開咬 4 名, 骨格性交叉咬合 2 名であった。術前および術後 1 年以上経過した 時点での顔貌写真を用い，1）顔面正中に対するオトガイ部の偏 位，2）下顎骨外形の左右差，3）口裂の傾斜を基準に，術前・術 後の顔貌の対称性を検討した。【結果】術前と比較し，1）顔面正 中に対するオトガイ部の偏位については 10 症例中 8 症例で改善 し，2）下顎骨外形の左右差については 6 症例で改善し，3）口裂 の傾斜については全例で改善した。安定した機能的咬合を得るこ とを目的に上下顎移動術を行えば，顔貌の非対称性についてもほ とんどの症例で改善されるが, 顎骨の形態や軟組織の影響によっ ては術後に非対称が残る可能性があることが考えられた。
A-1-4. 下顎後方移動術における側貌軟組織変化につい て

\section{-1. 鼻口唇形態における検討一}

\author{
岡山大学大学院医歯学総合研究科 \\ 歯顎口腔病態外科分野 \\ ○吉岡 徳枝，西山 明慶，佐々木 朗 \\ 神野歯科矯正 \\ 神野 時有
}

顎変形症は，咬合不全だけでなく顔面骨格形態の不調和を伴っ ていることが多く，近年，その治療においては調和のとれた上下 顎関係および咬合状態の獲得に加え，顔貌形態の改善という審美 的な要素を十分に考慮した治療が求められている。われわれの施 設においても，外科的矯正治療を積極的に行うことにより，機能 的のみならず審美的改善においても良好な結果を得ている。われ われは以前に第 10 回の本学会において，上下顎移動術前後にお ける側貌軟組織の形態変化について, 顔面測定学的に評価し報告 した。今回，下顎後方移動術を単独で施行した症例における術前・ 術後の側貌軟組織の形態変化について, 前回と同様に比較検討を 行ったので報告した。症例は 1997 年から 2002 年の 6 年間に当科 において下顎後方移動術を単独で受けた患者のうち，開咬，非対 称および口唇口蓋裂を伴わない 28 名を対象とした。患者内訳は 手術時年齢 16 歳から 39 歳, 男性 10 名, 女性 18 名で, 術式は下 顎枝垂直骨切り術 19 例，下顎枝矢状分割骨切り術 9 例であった。 術前・術後 6 か月目の軟組織側貌写真および頭部 X 線規格写真 について分析を行った。Naso-Labial angle および NasoFacial angle は術前，日本人標準值より小さな值を示していた が，いずれも術後に改善傾向を示し，鼻口唇形態の改善を認めた。 下顎後方移動単独でも Naso-Labial angle は改善し, LabioMent angleに打いても術前と比較して術後, 有意に改善した。 しかしながら，軟組織上の変化量と硬組織上の変化量には有意な 相関が認められなかった。軟組織の変化が連続した一連の流れで おこる一方，硬組織の変化とは明確な相関は認めず，軟組織の術 後変化予測を行うには今回の結果のみならず他の関連因子の解析 が必要と思われた。

\section{A-1-5. 下顎後方移動術における側貌軟組織変化につい} て

\section{一2. 熲部軟組織における検討一}

岡山大学大学院医歯学総合研究科 歯顎口腔病態外科学分野

○西山 明慶, 吉岡 徳枝, 佐々木 朗 神野歯科矯正 神野 時有

近年，顎変形症の治療において咬合の改善のみならず，審美的 要素を十分に考慮した治療が求められている。下顎前突症例にお いても機能的，かつ審美的な改善を考慮し，術式を決定しなけれ 
ばならない。われわれの施設においては，上下顎移動術を用いた 症例で, 審美的改善においても良好な結果を得ており, 第 10 回 の本学会において, 術前後における側貌軟組織の形態変化につい て, 顔面測定学的に評価し報告した。しかしながら下顎後退術単 独症例での検討はなされていなかった。そこで今回われわれは, 顂部軟組織の下顎後退術前後の変化について顔面測定学的に評価 検討したので若干の考察を加えその詳細を報告する。対象は 1997 年から 2002 年の 6 年間に当科において下顎後方移動術を単独で 受けた患者のうち, 開咬, 非対称および唇顎口蓋裂を伴わず，オ トガイ形成術を併用していない 28 名に対して評価した。患者内 訳は手術時年齢 16 歳から 39 歳 (平均 22 歳), 男性 10 名, 女性 18 名, 下顎枝垂直骨切り術 19 例, 下顎枝矢状分割術 9 例であっ た。側貌写真上で眼球から口角にいたる煩部軟組織の輪郭線をト レースし, フランクフルト平面およびこれと直交し外耳点を通過 する垂線を基準線とし術前・術後の眼窩下部, 煩部最突出点, 口 角部の位置変化, 側貌軟組織の形態変化について比較検討した。 また, 頭部 X 線規格写真分析を用い硬組織の変化との比較を行 うとともに, 上下顎移動術と下顎移動術単独との比較も行った。 下顎単独移動症例においても口角点の後方移動を中心として煩部 軟組織の形態に改善傾向が認められた。後方移動量が少ないとき には上唇, 煩部はむしろやや前方へ移動する傾向を示した。軟組 織の変化は各基準点がお互い関連しつつ変化していたが, 硬組織 の変化とは明確な相関がなく軟組織の術後予測を行うためには今 後軟組織の変化と, 硬組織の移動変化において影響を与える因子 の解析が必要であると思われた。

質問 中央矯正歯科クリニック 鈴木 純一

術前・術後, 特に術後の患者の体重増に関し, 頣部は変化して くると思う。体重増に関し何がなるものか。体重の増減は，大き な因子となると思う。

回答岡山大 · 大学院 - 歯顎口腔病態外科 西山 明慶 今回は計測しておりませんが考慮すべき点であると思います。 質問 横浜総合病院 - 歯口外今村 栄作 今回非対称症例は除外されたとのことですが，下顎正中を何 $\mathrm{mm}$ 以内を非対称なし対称と設定されたのでしょうか。

回答 岡山大 · 大学院 - 歯顎口腔病態外科 西山 明慶 歯牙正中のズレが $3 \mathrm{~mm}$ 以上のものを非対称として除外しまし た。

\section{A-2-1. 下顎非対称を伴う下顎前突症の術後評価}

鶴見大学歯学部口腔外科学第一講座

○石井 宏昭, 三井 周子, 野口 和秀, 荒 博 範, 中島 敏文, 園山 智生, 濱田 良樹, 近藤 壽郎, 清 水一, 瀬戸 晥一

今回われわれは, 下顎非対称を伴う下顎前突症にミニプレート 固定あるいはネジ止め固定を行った症例の術後評価を行い, とく に後戻りについてネジ止め固定との比較検討を行った。【対象】
ミニプレート群 10 例（男性 6 例，女性 4 例）手術時平均年齢は 男性 27.2 歳, 女性 23.3 歳。ネジ止女固定群 10 例（男性 3 例, 女 性 7 例）手術時平均年齢は男性 21 歳，女性 18.4 歳。【方法】術 前, 術直後, 術後 1 年の側面頭部 X 線規格写真を用いて, F-angle, SNB, Pogonionの前後的位置変化を計測した。また, 正 面頭部 X 線規格写真で左右顎角部の幅径を計測した。さらに後 方移動量, 術前後の顎関節症状, 知覚異常等についても検討した。 【結果】ミニプレート固定群では F-angle, SNB, Pogonion ともに術後の変化に有意差は認めなかった。後方移動量は回転側 $10.4 \mathrm{~mm}(9 \sim 13 \mathrm{~mm})$, 非回転側 $3.5 \mathrm{~mm}(0 \sim 7 \mathrm{~mm})$ 。顎角部幅 径では, 回転側, 非回転側ともに術前後を通して有意差を認めな かった。知覚異常は 20 側中 3 側, 顎関節症状は術前 20 側中 1 側, 術後は 20 側中 3 側であった。ネジ止め固定群ではセファロ分析 では術後の変化に差を認めなかった。後方移動量は回転側 10.5 $\mathrm{mm}(9 \sim 15 \mathrm{~mm})$, 非回転側は $4.3 \mathrm{~mm}(0 \sim 10 \mathrm{~mm})$ 。顎角部幅 径は回転側，非回転側ともに術前後を通して差を認めなかった。 知覚異常は 20 側中 13 側に認められ, 顎関節症状は, 術前 20 側 中 1 側, 術後も 20 側中 1 側であった。両群の比較をしたところ, 下唇の知覚異常に差を認めたが, その他のセファロ, P-A分析に おいて有意差はなかった。【考察ならびに結論】以上より，ミニ プレート固定はネジ止固定と同等の術後安定性を有することが 示された。

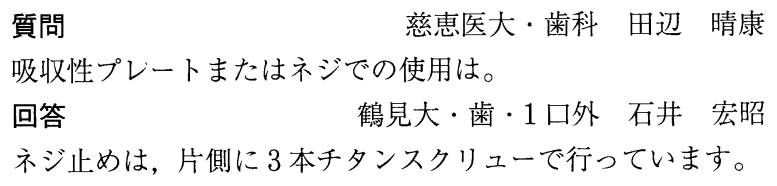

\section{A-2-2．上顎後方移動術における側貌の変化（鼻唇角を 中心に)}

福岡歯科大学口腔顎顔面外科学講座口腔外科学分野

○下田 恒久, 泉 喜和子, 田中 勝昭, 本田武司

福岡歯科大学口腔顎顔面外科学講座口腔腫瘍学分野 世良仁, 向坊 重広, 大関 悟

しもた矯正歯科クリニック 下田哲也

【はじめに】当科では上顎の前突, 臼歯のI級関係を示す症例の 治療が増加している。当科ではこの解決法として，1）Le Fort I 骨切り術に抜歯スペースを利用した上顎 3 分割（以下，上顎 3 分割術)，2）Le Fort I 骨切り術で翼状突起切離を行った上顎後 方移動 (以下, 上顎後方移動術), 3) Le Fort I 骨切り術に SSRO による下顎前方移動を併用 (以下, 上下顎移動術), など の 3 つの方法が施行されている。そこで, これらの個々の手術が 顔貌に及ぼす影響を検索した。【対象および方法】対象は, 過去 5 年間に, 同一術者によってLe Fort I 型骨切り術を施行した患 者 99 名のなかで, 上顎前突と診断され, 資料が整った 23 名であ る。その内訳は, 上顎 3 分割群 7 例, 上顎後方移動群 8 例, 上下 
顎移動術群 8 例の計 23 例で, 全例にオトガイ形成術が併用され ていた。調査項目は, 側貌の 5 つの審美三角と, 側貌の 3 つの審 美突出距離で, それぞれの計測值を術前後で比較し, paired T-testで統計学的に観察した。【結果】全症例の審美三角の術前 後の結果では, 顔面に対する鼻尖の突出が $5 \%$ の危険率で有意に 減少しており, 同様の傾向が, 上顎後方移動群で現れ, 顔面に対 して鼻尖が有意に後方へ移動していた。上顎 3 分割群と上顎後方 移動術群は, E-lineに対する上下口唇の位置が有意に改善されて いた。しかし，上下顎移動術では，全例にオトガイ形成術が併用 されているにも関わらず，上下口唇の有意な変化はみられなかっ た。【考察およびまとめ】上顎 3 分割群と上顎後方移動群は, E-line に対する上唇，下唇の前後的位置は有意に改善されていた が, 上下顎移動術群では変化がみられなかった。また, 上顎後方 移動術群で統計的に有意に顔面に対する鼻尖の突出度が減少し, 鼻尖の僅かな後退がうかがえた。しかし，上顎 3 分割術群では， 本法が鼻形態に悪影響を与えないことが推察された。

質問秋田大 - 医 - 口外 飯野 光喜

側貌に与える影響は, 後方移動量よりも上方への移動量や咬合

平面の傾斜の方が大きいと思いますがいかがでしょうか。

回答福岡歯大·顎顔面外科 下田 恒久

御指摘のとおり class IIでは Gummysmile を呈する症例が 多く, 今回提示した全 23 例は前歯部で $5 \mathrm{~mm}$ 程度の impaction を行っています。

Vertical な分析は次回行わせて頂きますが，われわれの立場 としては鼻形態に及ぼす影響の方が重要であり, 今回発表させて 頂きました。

\section{質問 宮崎医大 · 歯口外 迫田 隅男}

発表された症例すべてを上顎前突症の診断で発表されているが, 下顎にも病的状態があるからこそオトガイ形成術などを併用して いるのではないでしょうか。

回答福岡歯大·顎顔面外科 下田 恒久 今回の症例は II 級, 上顎前突例であり，下顎に対しては個々に オトガイ後退や下顎, 開咬等の重複診断を下せる症例が数多く含 まれています。

\section{A-2-3. 審美治療のゴール設定に用いる $\mathrm{Sn}-\mathrm{V}$ ラインの日 本人標準値について}

滋賀医科大学医学部歯科口腔外科学講座

○瀧上 啓志, 山口 芳功, 押谷 敏之, 西村一行, 岡 野 健, 坂本 耕造

歯, 顎骨の位置異常は, 顔貌における審美性に大きな影響を与 えていることは周知の事実である。このためこれらを治療する上 において，また審美歯科治療を進める上において，好ましい顔貌 を創り出す基準を考える必要があり，その值に基づいた治療が必 要となってくる。本邦においては，これまで好ましい側貌の基準 值として Ricketts の esthetic line や Steiner の lineが用い られてきたが，日本人に見られる鼻唇角が小さく，上唇の突出が
認められる症例においては, これらの值が正常域であるにもかか わらず，必ずしも良好な側貌を有するとは言えない症例に遭遇す ることがある。これはこれらの基準線は，鼻部ならびにオトガイ 先端を基準点としたもので，欧米人と骨格的に明らかに差異のあ る日本人において必ずしも同様の評価が行い得ないことによるも のと考える。そこで今回私達は, フランクフルト平面に対して垂 直な基準線 $(\mathrm{Sn}-\mathrm{V})$ に対しての上唇, 下唇, オトガイ部の水平 的位置関係について良好な側貌を有する成人ボランティア男 10 名, 女 10 名, 計 20 名より審美歯科治療のためのプロフィール基 準値を求めた。その結果, $\mathrm{Sn}-\mathrm{V}$ ラインに対して上唇は $3 \mathrm{~mm}$ 前 方, 下唇は $1 \mathrm{~mm}$ 後方, オトガイ先端は $6 \mathrm{~mm}$ 後方にあること がわかった。この基準值は歯，顎骨の位置変化にともなう審美歯 科治療を進める上で有用なひとつの方法であると思われる。

質問 慈恵医大・歯科 田辺 晴康

発表されたデー夕を実際の患者に応用するためにはいかにする のか。

回答 滋賀医大・歯口外 瀧上 啓志

これを用いてプレデイクショントレーシングを行い, 手術の計 画を立てている。また，術後の側貌評価に利用している。

質問 岡山大 ·大学院・歯顎口腔病態外科 西山 明慶

個体間差を除去するためには，実測值ではなく何らかの基準距 離を用いて補正值を求め用いた方が良いのではないでしょうか。

回答滋賀医大 ·歯口外 瀧上 啓志

この基準値に沿って評価すると日本人ではオトガイ形成術の施 行率は高くなります。しかし，このプロフィールが患者さんに受 け入れられるか否かは別で, 術前に患者さんに提示する資料の 1 つとして使用している。

質問 ひろせ矯正歯科 広瀬 久三

個体差のある顎変形症患者に対象として外科的矯正治療を計画 していく際，有効な数值だと思いますが，あまりそれにこだわり すぎると術前矯正治療の際の抜歯や顎形成術の追加などが思った 以上に必要になってくると思いますが，現実的にはどうされてい ますでしょうか。

回答 滋賀医大 · 歯口外 瀧上 啓志 垂直関係では顔面の垂直バランスを見るため比率で表わしてい るが, 水平関係においては, 比率表示は必要ではないと考えてい る。

\section{A-2-4. 顎機能異常を有する顎変形症患者に用いた下顎 枝垂直骨切り術の長期経過について}

\author{
滋賀医科大学医学部歯科口腔外科学講座 \\ ○山口 芳功, 瀧上 啓志, 押谷 敏之, \\ 西村一行, 岡 野 健, 坂本 耕造
}

これまで欧米の研究者を中心に, 顎関節機能異常の症状改善に, 顎関節切離術変法 modified condylotomy ならびに下顎枝垂直 骨切り術（以下 IVRO）が有効であるとの報告が多くなされてき ている。本邦においても，これまで顎機能異常を有する顎変形症 
患者の治療にIVRO を用いた治療は当科をはじめいくつかの報 告がなされているが, いずれも術後 1 年程度のものが多く, その 後の有用性について検討された研究は少ない。そこで今回, 私達 は当科における顎関節機能異常を有する顎変形症患者に用いた下 顎枝垂直骨切り術の比較的長期に渡る治療の有効性について検討 したので報告する。研究対象は, 顎関節機能異常を有する顎変形 症患者で, 両側下顎枝垂直骨切り術を行い, 術後少なくとも 3 年 を経過した患者の中で, 今回の調查に協力が得られた患者, 女性 55 , 男性 27 , 計 82 名である。手術時年齢は 17 歳から 43 歳（平 均 24.3 歳) であった。術中, 骨切り骨片間の固定は行わず, 術 後約 2 週間の顎間固定を行った。術後経過期間は 3 年 2 か月から 14 年 2 か月, 平均 8 年 2 か月であった。評価項目は, 顎関節疼痛 ならびに咀嚼筋の筋倦㤐感の状態, 顎関節雑音（クリッキング）, 顎運動状態についての臨床評価と，パントモグラム, MRIによ る下顎頭形態ならびに関節円板の位置変化について検討を行った。 それぞれの評価は術前, 術後 6 か月, 1 年, 3 年に行った。この 結果, 顎関節疼痛, 咀嚼筋の疼痛, 筋倦点感は, 術後早期に著明 な改善を示し, その後の経過観察期間においてもほほ同様の状態 を維持していた。

質問東京大 ·学院・只外 森 良之

IVRO での治療前後で clicking あるいは疼痛等の症状がかな り改善されていますが, 実際の関節円板の状態は術前後でどの様 に変化していたでしょうか。

回答 滋賀医大 - 歯口外 山口 芳功

長期経過に関しての調査はまだ行っていませんが, 術前, 術後 1 年の比較では約 $60 \%$ の関節円板の改善率が得られています。

質問 鶴見大·歯・1口外 石井 宏昭

1. 術後, 新たにTMDが発症した症例はありますか。

2. 術後 $1 \sim 3$ 年にかけて TMD が残存している症例は同じ症 例ですか。

回答滋賀医大 ·歯口外 山口 芳功

今回の調査対象は全例術前に TMD を有するものです。臨床的 には非常に少ない数ではありますが, 術前顎関節雑音がなかった 方が軽度ながら, 術後出現した症例は経験しています。

\section{A-2-5. Syndromic craniosynostosis 患者における上下} 顎歯槽不調和度の検討
東京大学医学部附属病院顎口腔外科・歯科矯正歯科 ○松崎 雅子, 須佐美隆史, 荻原 祐二, 今村 尚子, 崎山 美雪, 森 良之, 依田哲也, 富 塚 健, 小宮 徳春, 高戸 毅

【目的】Craniosynostosis の症例に対し手術を行う場合，外貌 と咬合の両面から検討を加えていかなければならない。このうち 咬合に関しては, 前後的関係のみならず, 上下顎幅径についても 把握し治療計画を立てる必要がある。そこで今回われわれは, こ れらの患者の側面頭部 X 線規格写真および歯列模型を用いて上
下顎不調和度について検討した。

【対象および方法】 Syndromic craniosynostosis 患者 10 名 （女性 6 名, 男性 4 名, 12 歳 10 か月～29 歳 2 か月）を患者群と し, 歯科矯正治療開始前の資料を用いた。側面頭部 X 線規格写 真からは上下顎の前後的位置関係の検討を行った。また, 模型分 析では第 12 回本総会で報告した方法に従い, 第一大臼歯部の歯 列弓および歯槽基底幅径を計測し, 上下顎幅径調和度の検討を行っ た。対照には, Angle I 級叢生の歯科矯正患者 10 名（Ｉ級群） の動的治療終了時，および外科的矯正治療を行った骨格性下顎前 突症患者 21 名 (II 級群) の歯科矯正治療開始前の資料を用いた。 【結果とまとめ】（1）側面頭部 X 線規格写真の計測から, 患者 群は I 級群や III級群に比べ上顎が小さく, また, 上下顎の前後的 位置関係を示す ANB, A-B plane, Wits appraisal より, 上 下顎の前後的不調和の改善には顎矯正手術が必要であることが考 えられた。(2) 模型分析から, 患者群は I 級群や吕級群に比べ上 顎の歯列弓幅径が小さく, 上下顎幅径調和度（上顎一下顎）につ いても，下顎に対し上顎の幅径が著しく小さくなっていた。この ことから, 上下顎歯槽幅径の不調和を改善するためには, やはり 顎矯正手術が必要と考えられた。また，四級群に比べ上顎幅径 調和度がさらに小さい傾向がみられ, craniosynostosis 患者の 術前矯正治療の際, 上顎拡大を必要とする症例が多いのではない かと考えられた。

質問 慈恵医大・歯科 田辺 晴康 患者群の中に舌の大小による変化はなかったか。

回答東大病院・顎口外・歯矯正 松崎 雅子

舌に関しては今回定量的解析はおこなっておりませんが, 特に 舌が大きいと認められる症例はみられませんでした。

質問 神奈川県立こどもセンター 小林 眞司 上下顎に限った関係だけではなく, 頭蓋顔面 ( $\mathrm{Po}, \mathrm{S}, \mathrm{Ba}$ 等) から見た，上下顎の位置関係はどうか。

回答 東大病院 ·顎口外 - 歯矯正 松崎 雅子 Craniosynostosis のような症例の場合, $\mathrm{S}$ や $\mathrm{N}$ の位置がかな り変位しており, 個人差が大きいため今回は検討項目に入れてお らず，上下顎の大きさに限定しました。

\section{A-3-1. 両側下顎枝矢状分割術における下顎骨近位骨片 の内外側方向の変位に関する検討}

\author{
秋田大学医学部歯科口腔外科 \\ ○飯野 光喜, 三好康太郎, 山 岡 薰, \\ 永井 宏和, 大貫 敬嘉, 福田 雅幸
}

【目的】両側下顎枝矢状分割術（BSSRO）は顎矯正手術におい て最も多用されている術式である。本研究の目的は BSSROにお ける下顎骨近位骨片の内外側方向の変位を明らかにすることであ る。【方法】対象は当科で BSSRO を行った骨格型下顎前突症 19 例（女性 18 例, 男性 1 例, 年齢 15 32 歳) である。術前と術後 半年以上を経過した時点で撮影した正面頭部 X 線規格写真を研 究資料とし，両側 Go 間距離および顔面正中に対する両側 Go の 
距離の変化を計測した。【結果】19症例の下顎の後退量は 2〜11mm であり, 後退量の左右差は 0.5 7.5mm であった。術 前と比較した術後の両側 $\mathrm{Go}$ 間距離の変化量は $-4.3 \sim+4.9 \mathrm{~mm}$ で, 下顎の後退量との関連は認められなかった。下顎非対称の程 度と近位骨片の変位との検討では, 偏位側近位骨片の Go と顔面 正中の距離は術前と比較して $-2 \sim+3.3 \mathrm{~mm}$ の変化を示し, 下顎 偏位量との関連は認められなかった。また非偏位側近位骨片の Go と顔面正中の距離は術前と比較して $-4.3 \sim+2.3 \mathrm{~mm}$ の変化 を示し, 偏位側と同様下顎変位量との関連は認められなかった。 【結論】今回の検討では, BSSROによる下顎近位骨片の内外側 方向の変位と下顎骨の後退量および下顎骨の偏位量との間には全 く関連が認められなかった。この結果は, BSSROによる下顎の 移動量や移動方向が近位骨片の内外側方向の変位に与える影響は 少なく, むしろ下顎骨の形態や分割状態の方が強い影響を持って いると考えられた。また，これまで指摘されているような下顎非 対称症例における偏位側近位骨片の外側方向へのはねあがり現象 もほとんど認められなかった。

\section{A-3-2. Le Fort I 型骨切り術のための CT による下行ロ 蓋動脈の走行位置の解剖学的検討}

\author{
横浜市立大学医学部附属市民総合医療センター \\ 歯科・ 口腔外科 $\cdot$ 矯正歯科 \\ ○河原日登美, 福山 英治, 斎藤 友克, \\ 海 野 智, 大村 進 \\ 東京医科歯科大学大学院医歯学総合研究科 \\ 咬合機能制御学分野 \\ 相馬 邦道 \\ 横浜市立大学医学部口腔外科学講座 \\ 藤田 浄秀
}

【目的】Le Fort I 型骨切り術に際し, 下行口蓋動脈の損傷は, 術中の多量出血に直結する重大な合併症として知られている。下 行口蓋動脈は上顎洞内側壁の後縁に位置し, 手術に際し梨状口前 縁から下行口蓋動脈までの直線距離はノミを用いて骨切りを進め るうえで重要な指標となる。今回われわれは CT 軸位画像を用い て梨状口前縁から下行口蓋動脈までの距離を計測し, 下行口蓋動 脈の損傷を回避し安全に Le Fort I 型骨切り術を施行するため の上顎洞内側壁の骨切りの長さを検討したので報告する。【方 法】最近 2 年 6 か月に当科において顎矯正術を施行した顎変形症 患者 42 名（男性 18 名，女性 24 名）に扔ける術前 CT を用いた。 計測は Kasey らの方法に準じ, Le Fort I 型骨切り線に相当す る鼻腔底から約 $3 \mathrm{~mm}$ 頭蓋側の横断像において, 梨状口前縁から 下行口蓋動脈までの直線距離を計測した。【結果】梨状口前縁か ら下行口蓋動脈までの距離は男性で平均 $39.31 \mathrm{~mm}$ （最小值 34.07 $\mathrm{mm}$, 最大值 $43.53 \mathrm{~mm}$, 標準偏差 $1.89 \mathrm{~mm}$ ), 女性で平均 36.38 $\mathrm{mm}$ （最小值 $31.11 \mathrm{~mm}$, 最大值 $42.47 \mathrm{~mm}$, 標準偏差 $2.91 \mathrm{~mm}$ ） であった。男性と女性において有意差が認められた。またそれぞ れの群において左右差は認められなかった。【結論】CT 画像によ
り梨状口前縁から下行口蓋動脈までの距離を症例ごとに計測する ことにより，上顎洞内側壁の安全な骨切りの長さの測定は容易に 可能であった。日本人においては, 下行口蓋動脈を損傷すること なく安全にLe Fort I 型骨切り術を行うための上顎洞内側壁骨 骨切りの目安は, 最小值を基準とすればおよそ $30 \mathrm{~mm}$ であるこ とが示された。

質問 洛和会音羽病院 中村信一郎

1. 加齢によって下行口蓋動脈と翼状突起までの距離が短くな る傾向があるとのことだが，それをどのように考察されますか。

2. 下行口蓋動脈と翼状突起までの距離が近い場合, Le-Fort I 型骨切り術の適応から外しているか, または, 何か工夫をして Le-Fort I 型骨切り術をされているか。

回答 横浜市大・医附属市民総合医療センター 河原日登美

1. 加齢とともに上顎洞底線が下方に移行すると一般に言われ ており，それを洞内の体積が増加すると考え，後方にも移行する と考えると, 後方距離が短縮するのではないかと, その可能性を 考えております。

2. 下行口蓋動脈は下方に行くに従い内側へ入っていきますの で，ノミを外側から入れて高い位置で切ろうとすると血管損傷の 可能性が高くなるので, 第二大臼歯より後方では下方に骨切り線 を設定しております。

\section{A-3-3. 下顎枝矢状分割術患者の顔面形態の経時的変化}

\section{佐賀医科大学医学部歯科口腔外科学講座 \\ 築山 鉄平}

【目的】顎矯正術前後における顔面軟組織の変化を調べ, 顎骨移 動量と顔面軟組織移動量の関係や術後の後戻りについて 3 次元的 に評価すること。【対象】1998～2000 年に佐賀医科大学付属病院 歯科口腔外科にて下顎枝矢状分割法による顎矯正手術を行った 34 例（男性 5 名, 女性 29 名, 平均年齢 20.6 歳)。【方法】顔面形態 はユニスン製レーザースキャナーで術前および術後 $3 ， 6 ， 12$ か 月目に計測した。得られたデータは Imageware 社 3 次元形状解 析ソフトウェアを用いて分析した。手術によって形態が変化しな い鼻根部から前額部にかけての範囲を最小二乗法を用いて適合さ せることで, 複数の顔面デー夕を重ねあわせ, 形態が変化した部 位とその変化の大きさを明らかにした。分析は, 下顎骨の移動量 と移動方向をもとにして, 左右対称で比較的直線的に後方移動さ せた症例と, 左右非対称に後方移動させた回転移動の要素が強い 症例とに分けて行った。【結果】1. 左右対称群, 左右非対称群と も, 術後 12 か月の時点で軟組織の明らかな後戻りは認められな かった。2. 下顎骨の後方移動量に対する軟組織の後方移動量の 割合が算出できた。【考察】従来行われてきた側貌頭部 X 線規格 写真による軟組織形態の分析に比べて, 本法は, 移動量が左右非 対称な症例において, より正確な分析が可能であった。左右非対 称群の分析は, 下顎骨の前後的な移動に加えて, 回転および下顎 骨全体の側方移動を考慮する必要があると思われた。今後は左右 臼歯部での後方移動量だけでなく前歯部被蓋の変化も考慮に入れ 
た分析も行いたい。

\section{A-3-4． 外科矯正治療前後における顔面軟組織の三次元 的分析}

\section{九州大学大学院歯学研究院口腔顎顔面病態学講座 口腔顎顔面外科学分野 \\ ○樋 口 䊍, 蔵原 慎一, 佐々木匡理, 堀之内康文, 竹之下康治, 白砂 兼光 九州大学大学院歯学研究院口腔保健推進学講座 寺嶋 雅彦}

【目的】術後予測顔貌を作成するための基礎デー夕を得るため， 軟組織の形態変化について, 手術前後に撮影した Computed tomography からの三次元再構築画像 (3D-CT) を用い, 手術 前後の軟組織の厚みを計測し, 手術による硬組織移動方向との関 係を調査する。【方法】対象は当科で下顎後方移動術を行った骨 格性下顎前突症患者のうち, 研究の趣旨を説明し同意が得られた 5 名。全例女性で, 手術時年齢は 19 39 歳 (平均 27 歳), 著し い開咬症や顔面非対称，唇顎口蓋裂などの患者は含んでいない。 本被験者に対して, 手術直前と術後 1 年以上経過後に CT 撮影を 行い, 得られたデー夕を三次元画像構築ソフトを用いて硬軟組織 の 3D-CT 像を構築した。これらのデータを三次元解析ソフト上 で位置合わせを行い, 術前, 術後の軟組織の厚みを上顎領域, 下 顎領域に分けて計測した。さらに同ソフトを用いて，手術による 下顎の移動方向と軟組織の厚みの関係を調査した。【結果】軟組 織の厚みは, 上下顎領域とも正中付近ではほとんど変化がなかっ たが，上顎では煩部，下顎では正中から外側へいくほど術前に比 べ術後に増す傾向にあった。また, 手術による硬組織の移動と軟 組織の厚みの関係を調べた結果, 後上方へ移動した症例では上下 顎領域とも厚みが増加しているのに対し, 後方のみ移動した症例 では上下顎領域ともほとんど変化がなかった。【考察】今回われ われが開発したシステムにより, 術前, 術後の硬組織の重ね合わ せを上顎骨，下顎骨でそれぞれ別々に行うことにより，下顎骨の 複雑な移動とは関係なく同部位を同一平面で計測することが可能 となった。今後, CT データのみで問題となる歯列周囲のアーチ ファクトの影響を避けるために, 非接触型三次元計測装置で撮影 した術前, 術後の顔面軟組織および歯列模型を $3 \mathrm{D}-\mathrm{CT}$ 一統合し, さらにデー夕を増やすことで精密な術後予測顔貌を作成するシス テムを開発したい。

質問岡山大·大学院·歯顎口腔病態外科 西山 明慶 骨格の変化による軟組織の変化ではない, 手術による腫脹等の 軟組織の変化は術後どの位の期間まで残っているか, 本方法から 何らかの情報は得られないでしょうか。

回答杂州大·大学院・顎顔面外科 桶口惣 手術直前と動的矯正治療終了後で術後 1 年以上経過した時期に 撮影しております。

\section{A-3-5. 顔面非対称患者顔面の三次元形態分析}
鹿児島大学歯学部口腔外科学第二講座
○石畑 清秀, 三村 保, 野添 悦郎, 太田 剛史, 比地岡浩志

顎変形症患者の外科的矯正治療においては，咬合と同時に顔貌 の審美性を改善することが重要であり, 診断, 手術方法の決定, 術後成績の判定等に際しては, 顎骨形態とともに顔面形態を評価 することが不可欠である。下顎前突や上顎後退など，上下顎骨の 前後的位置関係の不調和に起因する顔面変形の診断, 治療に際し ては, 側面頭部X線規格写真や側方顔貌写真上で角度や距離等の 計測を行う従来の二次元的分析手段が用いられる。それによって, 変形の生じている範囲や程度を判定し, あるいは視覚的に把握す ることが正中領域に関してはある程度可能である。一方, 顔面非 対称患者の顔面形態の診断には, 従来より, 正貌写真, 正面頭部 $\mathrm{X}$ 線規格写真, 軸位による下顎骨の X 線写真や三次元 CT 像な どが用いられているが, 顔面変形の程度や範囲を三次元的に評価 する方法は確立されていない。今回われわれは, 顔面非対称患者 の顔面形態を三次元的に計測評価する方法を確立し, 変形の生じ ている領域と変形の程度を定量的に明らかにするとともに, 顔面 非対称患者の顔面形態の診断や治療方針の決定に際して規準とな り得る三次元基準值図形を構築することを試みた。顔面非対称を 伴う碩変形症と診断された女性患者 10 名 (最低 17 歳, 最高 32 歳, 平均 21.7 歳）を対象として, 非接触型三次元表面形状計測 装置（VoxelanNHV300-M）を用いて術前後の顔貌形態を計測 し, 三次元画像解析ソフト 3D-Rugle IIIにて分析し, 以下の結 果を得た。1. 鼻翼最外側点から下方の人類学計測点が有意に偏 位し, 偏位側の表面計測点は正常群および非偏位側に比べ前方位 にあることが明らかとなった。2．曲率表示顔面画像上に設定し たみかけの顔面中心線によって, 顔面正中線の偏位を定量的に判 定することができた。みかけの顔面中心線の偏位は鼻下部から始 まり，下方ほど大であった。3．下顎骨の移動によって顔面非対 称は著しく改善されるものの, 術後も一部の領域に非対称が残っ ていることが確認された。

\section{A-4-1. オトガイ部変形症の治療経験}

\section{一骨延長術と 2 段階骨切り術の 2 例一}

\section{松江市立病院歯科口腔外科}

○石倉 信造, 中村信一郎, 多賀 智治

顎変形症治療において, オトガイ部の前後的な変形や下顎の正 中の変形位置異常により,オトガイ形成術を施行することはしば しばある。オトガイ形成不全のような変形に対して,一つの骨切 り線では，オトガイ部の前方移動量に制限があるため， 2 段階骨 切りによるオトガイ形成または骨延長法によるオトガイ部の前方 移動術が必要となる。この 2 段階骨切り術を施行した場合, オ卜 ガイ部の前方移動後の軟組織の閉創に苦慮する。当科ではそのよ うな症例の場合, 剝離した骨膜を反転することにより閉創してお 
り, 術後の哆開はみられない。また, オトガイ部の前方突出量は 患者本人の主観的な希望があるため, 術前に移動量を決定するこ とが困難な場合がある。このような症例に対しては，骨延長法が 適応となると考える。今回, 2 段階骨切りによるオトガイ形成術 をおこない，骨膜を反転して閉創した症例（症例 1）と骨延長に より延長量を患者本人に決定していただいた症例（症例 2）の概 要を報告する。

症例 1 は 35 歳女性。顔面非対称と交差咬合を主訴に平成 13 年 12 月 4 日来院。術前矯正治療後 Le Fort I 骨切り術および IVRO 術後に 2 段階骨切りによるオトガイ形成術を施行し, 吸収 性プレート(フィクソーブ®) にて固定した。

症例 2 は 47 歳男性。Gummy smile とオトガイ部変形症を主 訴に平成 14 年 2 月 4 日来院。左上顎臼歯部および右下顎臼歯部 の歯の欠損に対し, デンタルインプラント植立し, 上下顎部分骨 切り術と同時にオトガイ形成術を施行し，オトガイ部にマーチン 社製 Maxillary Distractor を左右に装着した。術後 1 週間後 より患者本人に骨延長を施行していただき，前方位置を決定した。 固定後はハンドル部分を切断し, 切断後 4 か月後に骨延長器を除 去した。

質問 横浜市大・医附属市民総合医療センター 大 村 進 オトガイ部骨延長方法を具体的に御教示下さい。

回答松江市立病院 - 歯口外 石倉 信造

チューリッヒディストラクターが完全に平行になっていなくと

も延長中にプレートが変形し前方への延長は可能である。（上顎 上方移動でも確認済)。

質問 大阪歯大 ·附属病院 $\cdot 2$ 口外 覚道 健治 2 段階法と骨延長の適応（区別）について。

回答松江市立病院 · 歯口外 石倉 信造 骨延長が軟組織延長患者本人による位置決めができるため, 最 適と思われるが, 口内に延長用ロッドが出る器材を知らないため, 皮膚瘏痕を考慮しなくてはならない特に女性には当科では適応と しない。

\section{A-4-2. 成長ホルモン産生性下垂体腺腫による高度な下 顎前突症に対し, Obwegeser II 法を施行した 1 例}

\section{福井医科大学歯科口腔外科学講座 \\ ○坪田 桂, 小笠原利行, 北川 善政, 佐野 和生}

骨格性下顎前突症に対する外科的矯正手術としては, Obwegeser-Dal Pont 法が現在最も広く臨床に応用されている。 しかし, 下顎の前突が著しく, $15 \mathrm{~mm}$ 以上の下顎後退距離を必要 とする症例では，骨片移動後に十分な骨接触面積が得られず，ま た, 下顎枝後部周囲の軟組織に緊張が生じるため, 術後の後戻り が生じやすい。今回われわれは, 成長ホルモン産生性下垂体腺腫 による高度な下顎前突症に対して, Obwegeser II 法を施行し， 良好な結果を得たので, その概要について報告する。【患者】 47
歳, 女性【初診】 2002 年 3 月 22 日【主訴】下顎の前突感, 咬合 不全【既往歴】特記事項なし【現病歷】 27 歳頃より, 下顎前突等 の顔貌の変化, 手足の肥大を自覚し徐々に進行するも放置。下垂 体腫瘍疑いにて, 2002 年 1 月 31 日, 当院脳神経外科受診。2002 年 3 月 5 日, 成長ホルモン産生性下垂体腺腫の診断のもと, 経鼻 孔経蝶形骨洞腫瘍摘出術を施行。2002 年 3 月 22 日, 当科紹介受 診となる。【現症】身長 $158 \mathrm{~cm}$, 体重 $70 \mathrm{~kg}$ で全身状態は良好。 当科初診時は成長ホルモンは $27.1 \mathrm{ng} / \mathrm{ml}$ (基準值 $6 \mathrm{ng} / \mathrm{ml}$ 以下) と高值であったが, 術前は 9.0 と低下した。顔貌所見では重度の 下顎前突で, dish face 状を呈していた。over bite $9 \mathrm{~mm}$, over jet $-10 \mathrm{~mm}$ と著しい反対咬合を呈しており, 叢生等は認めなかっ た。【処置および経過】2003 年 1 月 10 日, 両側 Obwegeser II法, Egyedi and Obwegeser 法による舌縮小術を施行。舌の切除に

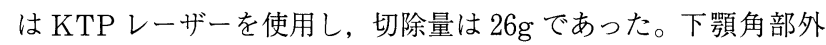
側の皮質骨を分割し口腔外へ取り出した後, 外側骨片, 内側の骨 を, 右側では下顎角部上縁で $16 \mathrm{~mm}$, 下縁で $25 \mathrm{~mm}$, 左側では 上縁で $17 \mathrm{~mm}$, 下縁で $28 \mathrm{~mm}$ の幅にて削除した。外側骨片を復 位させ, 外側骨片と近位骨片, 遠位骨片をそれぞれチタンプレー トにて固定し，顎間固定を骨 IMFを併用し 4 週間施行した。術 後の経過は良好であり, 現在, 外来にて経過観察中である。

質問 大阪大・歯・2 口外森 悦 秀

1. 手術シェーマでは下顎小舌より下に骨切り線があるように 見えましたが，下歯槽神経血管束の損傷の危険性はないでしょう か。

2. TMJ の位置付けは通常の SSRO と比べて難しいと思われ ますが，どのような工夫をされましたか。

回答福井医大・歯口外坪田 桂

1. 下顎管の位置が, 下顎骨上縁に位置しており, 骨切りは, 比較的容易に行えた。

2. 当科では, Condyleの位置決めを行っています。

回答福井医大 ·歯口外 北川 善政

1. 本症例では CT でみると下顎枝部の上方では, 海綿骨質が 消失していたためできるだけ下顎小舌に近い, 海綿骨質が存在す る部位で安全に骨切りを行いました。

2. 当科では下顎板と上顎の歯牙の距離を測定する簡易法で Condyle の位置決めを行っています。

質問 三次矯正歯科クリニック 鶴田 仁史

軟組織（咬筋や内側翼突筋）に対する取扱いは, 通常の Obwegeser-Dal Pont 法と異なる点がありますか。

回答福井医大 · 歯口外 北川 善政

Obwegeser II 法では，外側骨片をはずした後に，内側骨片を 移動量に応じて除去するために舌側骨膜下で内側翼突筋を剝離す る必要があります。 
A-4-3. コルチコトミーを併用し，治療期間の短縮をは かった症例について

\author{
福岡歯科大学口腔・顎顔面外科学講座 \\ 口腔腫瘍学分野 \\ ○世良仁, 向坊 重広 \\ 福岡歯科大学口腔・顎顔面外科学講座 \\ 口腔外科学分野 \\ 下田 恒久，泉 喜和子 \\ しもだ矯正歯科クリニック \\ 松下龍之助, 下田 哲也
}

【目的】歯列矯正治療において歯牙の移動を容易にし，治療期間 の短縮，および後戻り防止が期待できる治療方法として，歯牙歯 槽骨切り術 (alveolar corticotomy : 以下コルチコトミー) の併 用が報告されている。今回われわれは，外科矯正手術前あるいは 外科矯正手術時に，コルチコトミーを併用した症例について検討 するとともに若干の文献的考察を加え報告した。【対象と方法】 2000 年 12 月から 2003 年 6 月までに福岡歯科大学付附属病院にお いて顎変形症と診断され, 術前（3 症例）あるいは顎矯正手術時 （6 症例）にコルチコトミーを併用した 9 症例（12-39 歳）につい て臨床的に検討を行った。【結果・結論】術後に歯間乳頭部の退 縮や歯根や骨の異常な吸収など術後の偶発症を起こした症例は認 められなかった。また, 術後は速やかな歯牙の移動と緊密な咬合 関係が得られ，大幅な治療期間の短縮が可能であった。外科的矯 正治療時に，コルチコトミーを併用することは臨床的に有意義な 方法であり，患者の QOL の向上が可能になると考えられた。

質問 横浜市大・医附属市民総合医療センター 大 村 進

コルチコトミーは上顎口蓋側，下顎舌側をどのように処理され ているでしょうか。

回答福岡歯大 ·外世良 仁

基本的に唇，煩側で充分であると考えるが必要であれば舌， 蓋側にも行う。

質問 明海大 ·歯 ·矯正 鐘ヶ江晴秀

1.コルチコトミー後どれ位の期間をおいて, 歯に移動力をか けているのか。

2. (状態をみて判断しているとのことですが）何を目安に判 断しているのですか。

回答福岡歯大・只外 世良 仁

症例により異なるが, より早期に矯正力を負荷するようにして いる。
A-4-4. Asymmetrical rapid maxillary expansion と corticotomy を併用した成人下顎前突症の 1 例

\author{
横浜市立大学医学部附属市民総合医療センター \\ 歯科 · 口腔外科 ·矯正歯科 \\ ○福山 英治, 大 村 進, 河原日登美, \\ 関 洋一郎, 齋藤 友克, 海 野 智 \\ 横浜市立大学医学部口腔外科学講座 \\ 藤田 浄秀 \\ 東京医科歯科大学大学院医歯学総合研究科 \\ 咬合機能制御学分野 \\ 相馬 邦道
}

Surgically assisted rapid maxillary expansion は Le fort I 型に準じた骨切りに正中口蓋部の骨切りを加え左右の segment をほぼ対称的に拡大することが一般的な術式となっている。 今回われわれは，上顎狭窄をともなう成人下顎前突症患者に対し て，片側 Le fort I 型骨切りと同側の口蓋骨切りを加え片側のみ を拡大する Asymmetrical rapid maxillary expansion に前 歯部の corticotomy を併用して治療期間の短縮をはかることが できた症例を経験したのでその概要を報告する。症例：42 歳, 男 性。主訴：可能な限り短期間での反対咬合の改善。既往歴 : 尿管 結石, 糖尿病。現症：上顎歯列弓は狭窄し，咬合位において右側 第 2 大臼歯を除いて反対咬合を認めた。また上顎左側中切歯から 犬歯部に著しい叢生を認め, 下顎に対して上顎正中は $5 \mathrm{~mm}$ 左偏 していた。右側大臼歯部で早期接触を認め中心位では右側田歯部 のみ反対咬合を呈していた。咬合位において, overjet $-2 \mathrm{~mm}$, overbite $0 \mathrm{~mm}$, SNA $77.7^{\circ}$, SNB $79.4^{\circ}$, ANB $-1.6^{\circ}$ であっ た。処置および経過 : 全身麻酔下に上顎右側 Le fort I 型骨切り, 鼻中隔やや右側で鼻腔底骨切りおよび上顎左側中切歯から犬歯部 に corticotomyを行った。4 日間の待機期間の後, fan タイプ拡 大装置を 1 日 $0.8 \mathrm{~mm}$ ずつ, 10 日間で計 $8 \mathrm{~mm}$ の拡大を行った。 また同時に上顎前歯部にマルチブラケット装置を装着し拡大して 出来た正中の空隙に corticotomy を施した部位の歯を移動させ た。その後, 術後矯正を継続し, 治療開始上り9 か月で保定開始 した。まとめ: 叢生をともなう上顎歯列弓の狭窄に対し, 症例に よっては上顎の拡大方向を限定した Asymmetrical rapid maxillary expansion は治療期間を短縮する有効な手段になる と考えられた。

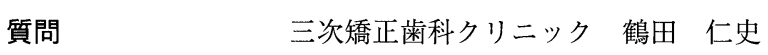

下顎の変形は下顎関節突起頸部の骨折によるものもあると考え られますが，下顎骨に対する手術術式として下顎枝垂直骨切り術 を選択することについてはどのように考えられますか。

回答 横浜市大・医附属市民総合医療センター 大 村 進 下顎も前方移動を予定したためSSROを適応いたしました。 質問 山王病院 高田 典彦 延長方向の設定の方法について。

回答 横浜市大・医附属市民総合医療センター 大 村 進 骨折のステップを解消する方向に設定しました。 
質問 北海道大 $\cdot$ 歯病 矯正 佐藤 嘉晃

1. 初診時の正面セファロにて，上顎の左右差（正中と $\mathrm{Mx}$ pointの差など）はありましたか。

2. 固定歯である左側臼歯部の煩側傾斜はみられませんでした か。

回答 横浜市大・医付属市民総合医療センター 福山 英治

1. 若干 P-A で上顎の左右の非対称は認められましたが，右 側のみ拡大を行うと, 上下顎の正中が右側に偏位することは予想 していました。しかし, 患者が治療期間の短縮を強く希望し, 正 中の偏位に了承が得られたため本術式を選択しました。

2. 若干, 歯が煩側に傾斜しながら拡大されています。しかし, 術前の set up model より, 左側は拡大の反作用で歯列が若干 expansionされるとちょうど被蓋がつくことが予想されました ので, 片側のみの拡大を行いました。

\section{A-4-5. 吸収性スクリューを用いた下䫟枝矢状分割術の 術後成績}

大阪大学大学院歯学研究科顎口腔病因病態制御学講座 口腔外科第 2 教室

○清水 英孝, 森 悦 秀, 南 克 浩, 應谷 美幸，由良 義明

当科の下顎枝矢状分割術（以下 SSRO）では，チタン製スクリュー による骨接合を行ってきた。チタン製スクリューは骨接合が強固 で生体親和性も優れている良い材料であるが, CTや MRI 撮影時 のアーチファクトの発生や金属イオン溶出の可能性などが問題に なることから撤去手術が必要であると考えられる。一方，近年開 発されたポリ-L-乳酸（PLLA）製骨接合材料は，吸収性である ため撤去手術の必要がなく，顎矯正手術にも用いられるようになっ た。しかしながら，PLLA 製スクリューはチタンに比べて強度 が劣るため術後安定性の得られる遠位骨片の移動範囲が不明確で ある。今回遠位骨片の移動様態に一定の条件を設定して SSRO の骨接合に PLLA 製スクリュー $\left(\right.$ FIXSORB $^{\circledR}-\mathrm{MX}$ ， タキロン 社製）を適用し，術後安定性の評価を行った。

当科において 2001 年 4 月から 2002 年 7 月の間に SSRO 単独 で施行した 40 例中， 10 例（男性 5 名，女性 5 名，年齢は 17 歳か ら 53 歳）を対象とし，PLLA 製スクリューを適用した。9 例は 下顎前突症で遠位骨片の後方移動量が $10 \mathrm{~mm}$ 以内でかつ著明な 非対称がない症例（左右の移動量の差が $5 \mathrm{~mm}$ 以内であるもの）, 1 例は下顎後退症で前方移動量は $5 \mathrm{~mm}$ であった。手術は全例 Obwegeser 原法に準じた骨切り線を設定し，近位骨片復位シス テムを用いて，片側 2 ないし 3 本ずつの PLLA 製スクリューを 用いて Bicorticalに骨接合を行った。術翌日より約 1 週間の顎 間固定を行い，固定解除後は旁引ゴムにて咬合誘導を行った。

術直後から術後 $1 ， 3,6$ か月間の経過を側方頭部 X 線規格写真 を用いて, B 点, Pog, Me の座標值の変化と SNB 角の角度的 変化を検討した。その結果水平方向への後戻りをほとんと認めず, 垂直方向への後戻りも $1 \mathrm{~mm}$ 以内であった。 $\mathrm{SNB}$ 角も移動量の
10\%以内の後戻りであった。開咬を伴った 1 例に後戻りを認めた が，牽引ゴムを再開することで回復した。

PLLA 製スクリューを遠位骨片の移動量が $10 \mathrm{~mm}$ 以内で左右 の移動量の差が $5 \mathrm{~mm}$ 以内の症例に応用したところ, 臨床上問題 のない術後安定性が得られた。

質問 北海道医療大・歯・ 口外 I 武藤 寿孝

1. チタンは，すべての患者に除去するように説明しているの ですか。

2.チタンによる副作用の報告はありますか。 回答 大阪大 ·学院 $\cdot 2$ 口外 清水 英孝 チタンスクリューは，当科に扔いて，撤去術を始めている。そ の理由として画像撮影時のアーチファクトや，金属アレルギーの 問題が考えられるからである。

A-5-1. 下顎骨骨延長後の早期固定に吸収性ミニプレー トを使用した 2 例

洛和会音羽病院京都口腔健康センター 青井 陽子，横江 義彦 京都大学大学院医学研究科感覚運動系外科学講座 口腔外科学分野 村上賢一郎，飯塚 忠彦

今回われわれは下顎頭，下顎枝形成不全による小下顎症の 2 例 に対し骨延長術を施行, 顎骨延長終了後早期に吸収性ポリ-L-乳 酸製骨接合材ミニプレート（FIXSORB $\left.{ }^{\circledR}-\mathrm{MX}\right)$ を用いて固定を 行い良好な結果を得たので報告する。【症例 1】初診時年齢 17 歳 6 か月女性。上顎前歯の突出を主訴に矯正歯科受診。X-P にて左 側下顎頭の形成不全が疑われたため当科紹介受診となった。現症; 口腔内所見 : overjet $+4 \mathrm{~mm}$, overbite $-2 \mathrm{~mm}$, 上顎正中は 顔面正中に一致, 下顎正中は左側へ $2 \mathrm{~mm}$ 偏位。臨床診断 : 骨格 性上顎前突症。治療方針：パノラマ, MRIにて左側下顎頭の進 行性下顎頭吸収が疑われた。下顎頭への負担軽減のため両側下顎 枝の顎骨延長を行う事とした。治療経過 : H14 年 8 月 5 日両側下 顎枝にデイバイス（ライビンガー社）を装着, 術中に $2 \mathrm{~mm}$ 延長, 術後 7 日目より延長開始，両側ともに $15 \mathrm{~mm}$ の骨延長を行った。 同年 9 月 19 日ディバイスを除去し吸収性ミニプレートを両側に 各 1 枚使用し固定を行った。【症例 2】初診時年齢 8 歳 1 か月男子, 歯列不正を主訴に近医歯科受診，X-P にて左下顎枝部の形成不 全を指摘され当科受診。既往歴: 第 1 第 2 鰓弓症候群, 睡眠時無 呼吸症候群。現症; 全身所見: 肥満。口腔外所見 : Purzansky 分類 Type $2 \mathrm{~A}$, 下顎の左側偏位。口腔内所見 : overjet $+6 \mathrm{~mm}$, overbite $+5 \mathrm{~mm}$ 。咬合平面は左上がりの傾斜。臨床診断 : Hemifacial microrosomia。治療方針：左下顎枝部の顎骨延 長術。治療経過 : 術前矯正開始後, H14 年 8 月 1 日左下顎枝部に ディバイス (メディコン社) を装着し術中 $2 \mathrm{~mm}$ 延長, 術後 6 日 目より延長開始。術後 17 日目で $15 \mathrm{~mm}$ の延長を行った。同年 11 月 7 日デイバイス装置除去し吸収性ミニプレート1枚にて固定を 行った。結果：顔貌の非対称，咬合平面傾斜は改善され睡眠時無 
呼吸もほぼ認められなくなった。結果：後戻りを SNB, N-Pog to SN にて計測。症例 1 はデイバイス除去後約 8 か月時に計測。 後戻りは認められなかった。症例 2 はディバイス除去後約 7 か月 時に計測。SNB $3.3^{\circ}, \mathrm{N}-\mathrm{Pog}$ to SN では $2.8^{\circ}$ の後戻りが認め られた。これは延長後長期にわたり咬合が確保，顎間ゴムや保定 装置の使用がなされていなかった事に起因すると思われる。延長 装置の早期除去に伴う幼若で咬合の負担が加わる部位の骨の安定 性, 後戻りに対し再度抜釘の必要がなく骨形成を阻害する因子が 少ないと思われる吸収性プレートを使用した。現在感染兆候もな く経過良好である。

質問 明海大・歯・矯正 川島 成人

1. Case 2 で, Sleep Aprea に関する症状があったようです が術後変化はあったのでしょうか。

2. 肥満 BMI はどれくらいでしたか。

回答 洛和会音羽病院 青井 陽子

1. SAS は改善した。全く認められなくなったと家人から報 告があった。

2. 症例 2，8歳男児の体重は約 $120 \mathrm{~cm} ， 40 \mathrm{~kg}$ であった。 ローレル指数 190 でした。

質問鹿児島大・歯・只外 2 野添 悦郎

吸収性プレートを装着する際の位置やその際の工夫 etc，あり ましたら教えて下さい。

回答洛和会音羽病院 青井 陽子

延長装置固定箇所をさけ，後戻り防止のため両端の母床骨に延 長措置固定箇所よりやや下線で固定している。

\section{A-5-2. 口唇修正術に先立って上顎骨の垂直的骨延長術} を行った両側性唇顎口蓋裂

横浜市立大学医学部附属市民総合医療センター
形成外科
○長西 裕樹, 鳥飼 勝行
神奈川県立こども医療センター形成外科
小林 眞司
横浜市立大学医学部附属病院形成外科
前川 次郎
横浜市立大学医学部付属市民総合医療センター
歯科・ 口腔外科・矯正歯科
福山 英治, 大 村 准

一般に唇顎口蓋裂の術後顎変形は三次元的に小さな鼻上顎複合 体を本態としている。それに基づく咬合不全に対して歯科矯正治 療では前側方に歯列拡大して反対咬合の改善を行うが, 垂直的な 短縮に対しては改善目標としないことが多い。一方で，口唇や外 鼻の修正手術は矯正治療により再構成された硬組織のベース上で 行われることが多く, 変形した硬組織形態に軟組織形態の方を適 合させることを余儀無くされてきた。今回われわれは，上口唇の 短縮やそれに伴う naso-labial angle の狭小が前述の硬組織形 態の不完全な改善に起因すると思われる両側性唇顎口蓋裂症例に
対して口唇形態改善に先立って, 上顎の垂直方向への骨延長を行っ たのでその概要を報告する。症例は 20 歳女性。下口唇瘦孔を伴 う両側唇顎口蓋裂で, 生後 3 か月に Manchester 法での口唇形成, 1 歳 6 か月に push-back 法で口蓋形成, および下口唇㾇切除術 を受けていた。その後鼻修正, 顎裂部骨移植術を施行され, 就職 前に口唇変形, 顎変形の修正を希望して当科を受診した。上口唇 の短縮，下顎前突様顔貌を認めたが，咬合は overbite, overjet とも $3 \mathrm{~mm}$ に矯正されていた。側面セファロ分析では, 上顎骨劣 成長は主に垂直方向に存在し，その結果 occlusal plane が flat で, 下顎骨の反時計回転による二次的な下顎前突を呈していた。 手術計画立案時に, 軟組織の改善のみ行っても incisal show の 消失を含めて, 良好な facial balanceの獲得は困難と予測され た為, 軟組織修正に先立って硬組織の形態改善を先行させる方針 とした。手術は, Le Fort I 型骨切り後に, 上顎骨前面左右に 下顎歯槽骨垂直延長用の骨延長器を装着した。latency period を一週間おいた後， $0.9 \mathrm{~mm}$ /日の割合いで 6 日間，合計 $5.4 \mathrm{~mm}$ 延長した。上顎歯槽部が Rigid に固定され平行に延長されたな らば下顎臼歯との早期接触が発生し open bite を呈することにな るが, 本症例では延長器装着部位を前方に求めたため, 延長方向 は咬合力により調整され，下顎の時計回転に合った形での上顎骨 延長を実現した。現在，軟組織の修正手術前であるが balance を取り戻した硬組織に合わせて思想的な軟組織形態獲得が期待さ れる。以上のことょり本法は唇顎口蓋裂患者の上顎術後変形に対 する根治的療法の選択の一つと考えられた。

質問北海道大 ·学院 - 補経 大畑 昇

1. 上顎骨の垂直的骨延長術を行うのではなく，前歯と正を 補緅してから，鼻，口唇修正術（骨移植を含めて）を行うという 選択枝はなかったのですか。

2. 最終的に上顎前歯の補綴はどのように考えているのですか。 回答横浜市大 · 形成 長西 裕樹

患者さんの主訴が，上口唇の短縮だったので，それを改善する 事を前提として治療を計画しました。骨移植か, 骨延長か選択に 関しては, 本症例の上顎成長の原因が, 上顎前面䫟裂の瘏痕組織

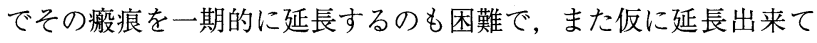
も, その張力が移植骨にかかり骨吸収が著しいと考え, 骨延長法 を選択しました。

質問洛和会音羽病院 中村信一郎

TRACK System を用いられましたが, 延長方向に対して正 確に設置するために何か工夫されましたか。

回答横浜市立大・医・形成外科 長西 裕樹

1. 上顎前面は前下方に傾斜しておりフランクフルト平面に垂 直に固定するには骨切り線上側の固定部を折り曲げ骨面より浮か して装着しています。

2. 特に工夫はせず，術中所見により臨機応変に対応しました。 上顎前方部に 2 個装着したため, その平行性は比較的容易に確認 出来ました。

質問 香川県立中央病院 - 歯口外 三次 正春

1. 同様に上口唇が短縮していても，ボリュームが十分にある 
症例では, closs-lip 手術をするのか。

2. 硬口蓋と鼻中隔軟骨の離断はされているのか。されたなら 鼻変形を起こしていないのか。

回答横浜市大 · 医 - 形成外科 長西 裕樹

1. 本症例でも，骨延長後に上口唇は延長しています。当然， free marjin は延びるのではなくSubnasal の軟部組織が, 下方 移動したANSに引き伸ばされた結果です。その意味では症例に よっては口唇形成は必要ないかも知れませんが, あくまでセファ ログラム上の形態の評価で表情を構成部分として, 良好な機能が あるかは分かりません。

2. 離断はされています。

回答横浜市立大 ·医 ·形成外科 鳥飼 勝行

特にその事による鼻変形はありません。今後予定している鼻修 正はAbbe flapによる鼻翼幅の増大を修正するものです。

\section{A-5-3. 唇顎口蓋裂に起因する上顎劣成長に対し RED} system による骨延長を行った 3 症例

\author{
京都大学医学研究科口腔外科学 \\ ○尾一祐, 村上賢一郎, 高 橋 克, \\ 野中太一郎, 横江 義彦, 安田 真也, \\ 飯塚 忠彦 \\ 洛和会音羽病院 \\ 吉田 和也
}

【はじめに】：口蓋裂に起因する上顎の前後的ならびに垂直的劣 成長を伴う成人顎変形症 3 症例に対して, RED システムによる 上顎骨の骨延長を行い，良好な結果を得ているので報告する。

【対象症例】: 3 例（男性 2 例，女性 1 例）の原疾患の裂型は UCLP で，年齢は $17 \sim 18$ 歳であった。 3 症例の咬合関係は以下 の通りであった。

症例 1 ; overjet $-13 \mathrm{~mm}$, overbite $-5 \mathrm{~mm}$, Angle 3 級, 症例 2 ; overjet $-2.5 \mathrm{~mm}$, overbite $1.5 \mathrm{~mm}$, Angle 1 級, 症例 3 ; overjet $-6.5 \mathrm{~mm}$, overbite $3 \mathrm{~mm}$, Angle 3 級。 【骨延長法】：最初にメタル製の口蓋床を装着, Le Fort I 型骨 切り術を施行，上顎の可動性を確認して，骨延長装置を装着した。 待機期間は 3〜5 日間とし，骨延長は 1 日 $0.8 \sim 1.6 \mathrm{~mm}$ で，症例 毎に 7 15mm の前方，または前下方への延長を行った。また咬 合平面の傾斜の修正 (ローテーション)，あるいは歯列弓の縮小 または拡大を同時に行った。骨延長終了から上顎骨の固定手術ま での期間は 1 7 日間で, 2 症例で Lorenz の，1 症例で CMS の micro-plate を用いて上顎骨の固定を行った。またその際に同時 に下顎の骨切り術を 2 症例に行った。

【結果】: 3 例とも骨切りした骨片の血行は良好で, 上顎骨切り術, 延長装置の装着に問題はなかった。但し，骨切り後，上顎骨の可 動性は得られたものの瘷痕が強く, Down fractureに抵抗が強 かった。しかし，延長装置をセットし，骨の延長が可能であるこ とを術中に全例で確認した。骨延長に伴う局所の強い疼痛や骨延 長の中止例はなかった。ただし, RED システムのヘッドフレー
ムの固定用ロッドによる疼痛の訴えはあり, 症例に応じて緩和し た。ロッドは左右側頭部に 3 本ずつ計 6 本でヘッドフレームを固 定した。全例で中顔面の明らかな顔貌の改善と良好な咬合関係が 得られた。手術終了から現在まで最長 3 年, 最短 4 か月を経過す るが，後戻りなく，良好な経過を見ている。

【考察】: 上顎の骨切りと一期的前方移動が困難な口蓋裂症例に 対して RED システムを用いた上顎骨延長術は臨床的に有用と考 えられた。

質問 大阪歯大・只外 2 覚道 健治

$\mathrm{RED}$ システム施行と同時に歯列弓の拡大を行うプロトコール についてご教示下さい。

回答京都大 - 医 - 口外 中尾一祐

歯列弓の変形および, 前方移動は同時に開始し, 歯列弓の変形 が終了した後は，前方移動のみを行っております。

質問 香川県立中央病院・歯口外 三次 正春

RED 装置に工夫しているとのことですが, 垂直的にも骨延長 が図れましたか。

回答 京都大・医·口外 中尾一祐

左右それぞれに対し，移動可能なことに加え，下方移動も可能 になっています。

質問 氏名不詳

Consolidation 期間は RED の除去までを言っているのです か。

回答 京都大・医・ 口外 中尾一祐

そうです。 RED 装置を除去し，プレート固定をするまでです。

\section{A-5-4． 口唇口蓋裂患者における上顎骨骨延長 一RED system と Zürich 型装置を経験して一}

東京大学医学部附属病院顎口腔外科 · 歯科矯正歯科 ○森良之, 江口 智明, 須佐美隆史, 小泉 敏之, 松崎 雅子, 荻原 祐二, 崎山 美雪, 今村 尚子, 富 塚 健, 近津 大地, 依田 哲也, 高戸 毅

口唇口蓋裂患者において㓔痕の強い症例では, 一期的な Le Fort I 型骨切り術では予定した前方移動量を獲得できず，後戻 りを生じることが多い。このような症例に対して，われわれは骨 延長法を用い, 上顎の前方移動を行っている。今回, 創外延長器 である RED system と口腔内延長器である Zürich 型装置の両 装置を使用して, 若干の知見を得たので報告する。【方法】1: RED system; 18 歳女性・口蓋裂, 13 歳女性・両側口唇口蓋裂, および 17 歳男性・左側口唇口蓋裂の 3 例を対象とした。Le Fort I 型骨切り術を行い, down fracture させた後ハロー型上 顎骨延長装置（RED system; martin 社）を装着した。上顎フェ イスボーを利用した牵引用口腔内装置は術中に装着し, 術後 $3 \sim 5$ 日目より $1 \mathrm{~mm} /$ 日の延長で, 最大 $14 \mathrm{~mm}$ の上顎前方移動を行っ た。延長終了後 3 日〜 7 日目で, 延長装置を除去するとともに, 顎間ゴムにて上顎を誘導した後, 顎間固定を施行した。その後, 
フェイシャルマスクと顎間ゴムを用いて経過観察を行った。2： Zürich 型装置; 17 歳男性・左側口唇口蓋裂㧍よび 21 歳男性・左 側口唇口蓋裂の 2 例を対象とした。Le Fort I 型骨切り術を行い, モビライザーのみで上顎歯槽突起の可動性を獲得し, 口腔内上顎 骨延長器 (Zürich Pediatric Maxillary Distractor : martin 社）を装着した。術後 5 日目から $1 \mathrm{~mm} /$ 日の延長量で $6 \sim 8$ 日間 延長した。延長終了後 $1 \sim 2$ 週目に, 下顎骨骨切り術と同時に延 長器を除去し, 骨片のプレート固定を行った。術後顎間ゴムを使 用し, 経過観察を行った。【結果】口腔内外の両装置ともに, 上 顎骨の前方移動に有用であった。Zürich 型装置では延長後の骨 片の固定が比較的容易であったが, 延長量に制限があるため over correction は困難であった。一方 REDsystem では, 頭 部へのピン刺入による肉体的, 精神的負担が大きかったが, 十分 な延長量が得られ, 上顎移動量の大きい症例では RED system が第一選択と考えられた。

\section{質問 北海道大 - 歯 - 矯正 佐藤 嘉晃}

1. 顎裂を伴う症例で Bone graft を行っていたかどうか，ま たその影響力があるかどうかをおしえて下さい。

2. RED システムで, 鼻から wire を出した場合, 前下方へ の延長に伴い少し㿍こんができると思われますが，いかがですか。 東京大·顎口外・歯矯正歯科 森 良之

1. チューリッヒディストラクターで上顎延長を行った 1 例 （症例 5）は，顎裂骨移植が行われておらず，上顎を一体化するた めに上顎歯裂の Arch wireに加えパラタルバーを装着して延長 した。延長の途中では左右のアンバランスが多少生じたが, 2 回 目の手術で固定（プレート）を行うことにより，術後の結果は良 好であった。

2. RED での牵引により前下方向への上顎移動が認められた が over correction しているため, 上顎プレート固定時には予定 の位置への control は比較的容易に行えた。

質問 岡山大 · 大学院 - 歯顎口腔病態外科 西山 明慶 後戻りをみこして固定するとの事ですか, planning して術中 に位置決め等して固定されるのですか。

回答東京大・医 - 口外森良之

術前のセファロおよび模型分析からは，上顎前方移動距離はあ る程度決定されているため, それに従って 2 回目の手術では骨片 固定を行った。その際, 骨に刺入したチタン製のピンを目安とし た。

\section{A-5-5. 下顎骨延長術を施行した Nager 症候群の 1 例}

\author{
新潟大学大学院医歯学総合研究科 \\ 口腔生命科学専攻顎顔面再建学講座 \\ 組織再建口腔外科学分野 \\ ○小林 正治, 加納 浩之, 加藤 健介, \\ 齊 藤 力 \\ 新潟大学大学院医歯学総合研究科 \\ 口腔生命科学専攻捸食環境制御学講座 \\ 咬合制御学分野 \\ 新 垣 晋, 渡辺 直子 \\ 矯正歯科石井クリニック \\ 石井一裕
}

Nager 症候群は, 上肢の軸前性優位の形成不全, 小下顎症, 煩骨低形成，口蓋裂などを主症状とする比較的稀な症候群である。 今回, われわれは本症候群患者に対して両側下顎骨延長術を施行 し, 術後の顎位の変化について検討したので報告する。【症例】 患者は, 1 歳 7 か月時に開口障害にて当科を紹介され来院し, 小 下顎症と類骨低形成，口蓋裂，合指症を認めた。顎関節部に明ら かな癒着は認めず, 10 歳時に撮影した CT 画像より筋突起部の過 長が開口障害の原因と考え, 筋突起切除術を施行したところ開口 量は $18 \mathrm{~mm}$ から $27 \mathrm{~mm}$ に改善した。さらに，11 歳時に口蓋形成 術を施行した。その後, 小下顎症に対して下顎骨延長術を施行す る予定で術前矯正治療を開始した。平成 14 年 7 月 27 日, 13 歳時 に両側下顎枝部の骨切りならびに創内延長装置の装着を行い,さ らにLe Fort I 型骨切り術を施行して下顎骨とともに上顎骨の 移動を図ることとした。術後 5 日目から朝晚 $0.5 \mathrm{~mm}, 1$ 日 $1 \mathrm{~mm}$ の延長を開始したが, 延長装置を $13.5 \mathrm{~mm}$ 延長したところで延 長装置の変形と下顎枝後縁部の延長不良が確認されたため, 延長 を中止した。 8 月 24 日に両側とも延長装置を除去し, 下顎枝後縁 に沿って別タイプの延長装置を装着した。5 日後より 1 日 $1 \mathrm{~mm}$ の延長を開始し, 右側で $6 \mathrm{~mm}$, 左側で $8 \mathrm{~mm}$ の下顎骨延長を行っ た。さらに, 延長終了 3 か月後に延長装置の除去とオトガイ形成 術を施行した。術前とオトガイ形成術直後ならびに 1 年後に撮影 した頭部 X 線規格写真を比較検討したところ，下顎骨延長によっ て $\mathrm{B}$ 点で前方に $8.6 \mathrm{~mm}$, 下方に $8.4 \mathrm{~mm}$ 移動し, さらにオトガ イ形成術に伴いポゴニオンでは前方に $14.4 \mathrm{~mm}$ ，下方に $9.9 \mathrm{~mm}$ 移動していた。術後 1 年までに上顎骨は成長に伴い ANS で前方 に $2.4 \mathrm{~mm}$, 下方に $1.1 \mathrm{~mm}$ 移動していたが, 下顎骨の成長は認 めず時計回りに回転し，B 点で後方に $0.2 \mathrm{~mm}$, 下方に $1.1 \mathrm{~mm}$, ポゴニオンで後方に $2.1 \mathrm{~mm}$ ，下方に $0.7 \mathrm{~mm}$ 変化していた。

質問 北海道大 - 歯矯正 佐藤 嘉晃

1. 術前の下顎の前方および下方への予定 Distraction 量をお しえて下さい。

2. 臼歯は開かなかったのですか。

回答新潟大 ·学院・ 口腔再建外科 小林 正治

延長方向は, 下顎枝の垂直方向への延長が主となるように設定 し， 臼歯部に生じる開咬に対して Le Fort I 型骨切り術によっ 
て対応することとしたが，実際には，臼歯部に開咬は生じず，上 顎骨を動かすことはできなかった。

A-6-1. 下頡枝の Backward Distraction Osteogenesis による骨延長を行った 1 例

\author{
金沢大学大学院医学系研究科歯科口腔外科学分野 \\ ○島田 真弓, 上木耕一郎, 丸川 浩平, \\ 高桜 大輔, 中川 清昌, 山本 悦秀 \\ にいざわ歯科医院 \\ 新沢茂
}

両側下顎頭の大きさの違いや片側下顎骨の低形成は, 顔面非対 称の発症に関係する。今回右側の咬合と顎位を決めた上で, 左側 下顎枝の Backward Distraction Osteogenesisによる骨延長 と上顎骨側方拡大を施行し, 左側の交叉咬合および咬合平面の改 善を行った症例の概要を報告する。

症例 : 32 歳女性

主訴 : 審美障害

既往歴・家族歴 : 特記事項なし

現病歴 : 20 歳頃から左側煩部の突出感が気になり, 通院中の歯 科医院に相談したところ精査を钦められ，平成 12 年 6 月 21 日当 科初診となった。

現症：顔面非対称，左側臼歯歯列のみ交叉咬合で，咬合平面は 左上がりであった。オルソパントモにて左側下顎頭が右側下顎頭 と比較して小さかった。

処置および経過: 平成 12 年 7 月術前矯正を開始した。平成 13 年 6 月 5 日全身麻酔下に上顎は Le Fort I 型骨切り術と口蓋三 分割を, 下顎は両側に下顎枝矢状分割術を行い, 上顎には急速拡 大装置を，下顎には左側に仮骨延長装置を装着した。また右側の 上顎前歯部，臼歯部抢よび下顎はチタンプレートにて固定した。 術翌日から右側上下顎は顎間固定を行い固定源として, 左側上顎 の側方拡大と左側下顎の Backward Distraction Osteogenesis による下顎枝の骨延長を行った。延長 15 日間，上顎の 側方拡大は $4.5 \mathrm{~mm}$, 下顎は $13.0 \mathrm{~mm}$ 延長した。延長終了後の 6 月 26 日，全身麻酔下に左側下顎部の延長装置を除去し，吸収プ レートにて固定した。また上顎も同様に吸収プレートにて固定し た。現在, 術後 1 年 9 か月経過しており, 安定した咬合状態が保 たれており，患者の満足も得ている。

\section{質問}

1. 延長装置の方向設定について。

2. プレート固定した理由。

回答金沢大 · 大学院 - 歯口外 島田 真弓

1. 術中に延長方向を確認しています。

2. 患者さんの治療期間の短縮の希望により行いました。
A-6-2. 上䪽後退，下顎前突症例に対して上顎骨延長お よび下顎枝矢状分割術を適用した 1 例

\author{
昭和大学歯学部第 1 口腔外科学教室 \\ $\bigcirc$ 代田 達夫, 斉藤 浩人, 大野 康亮 \\ 昭和大学歯学部歯科矯正学教室 \\ 中納 治久 \\ 大和徳洲会病院歯科口腔外科 \\ 松原 太明，中村 篤
}

顎口腔領域における骨延長術は, 顎骨発育不全症などの顎変形 症に有効な治療法であるとされている。今回, 上顎骨が劣成長で 下顎の過成長により著明な反対咬合を来した症例に対し，High Le Fort I 型骨切り後, 創内型の骨延長装置を用いて上顎の骨延 長を行い，さらに下顎枝矢状分割術を抢こなうことによって良好 な結果が得られたのでその概要について報告する。症例は 18 歳 男性で，不正咬合を主訴として来科した。初診時， overjet -18 $\mathrm{mm}$, overbite $2 \mathrm{~mm}$ と著しい反対咬合を認めた。また，側方 セファログラム分析では, ANBが-6.0で，上顎の劣成長と下顎 の過成長が認められた。そこで術前矯正治療後, High Le Fort I 型骨切り術を行い, 創内型の上顎骨延長装置を装着した。術後 7 日目より 1 日あたり $1 \mathrm{~mm}$ の速度で 14 日間延長を行った。骨 延長中は下顎側方歯群との空隙に対応し，また下顎の顎位を決定 するために可撤式のバイトプレートを使用した。また，上顎の下 方への移動を可及的に防止するために骨延長中はフェイスマスク を装着させた。上顎骨延長後 4 か月目に骨延長装置の撤去および 延長部のプレート固定を行った。また，同時に下顎枝矢状分割術 を行い，下顎を左側 $10 \mathrm{~mm}$, 右側 $13 \mathrm{~mm}$ 後方移動させた。現在， 動的治療終了後約 6 か月経過しているが, 顔貌は改善され, また, 良好な咬合関係と顎機能状態が維持されている。

\section{A-6-3． Le Fort II ・III 型骨延長法における歯牙支持に頼} らない顎間ゴムの応用

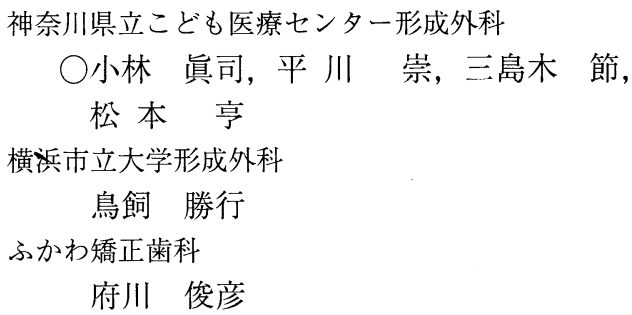

【はじめに】近年，上顎の劣成長に骨延長術が行われるようになっ ているが，その延長方向の安定性・正確性はいまだ確立している とは言い難い。特に craniosynostosis syndromeに対する一 期的骨延長法で中顔面の形態と咬合をともに満たすことは難しい。 われわれは独自に開発した延長器を用いているが，顎間ゴムを併 用することで延長方向のコントロールをより確実なものにしてい る。その際に歯牙年齢に応じて歯牙の挺出を防ぐ工夫を行ってい る。【対象と方法】対象は 2 歳 2 か月から 20 歳までの cranio- 
synostosis syndromeの 15 症例である。歯牙年齢により $2 つ$ の方法を用いた。1）上下顎骨に A.B. スクリューを打ち込みワ イヤをスクリューとアーチワイヤに固定し，アーチワイヤに取り 付けたフックに顎間ゴムをかける。2）固定源となる歯牙がほと んど存在しない乳幼児などの場合は上下顎骨の歯槽形態に合わせ てプレートを作成し，上下顎骨各々に circumferencial にワイ ヤを通し固定する。あらかじめプレートに装着しておいたフック に顎間ゴムをかける。【結果】 A.B. スクリューを打ち込みワイヤ をスクリューとアーチワイヤに固定する方法は簡便で, 歯牙の挺 出なく顎間ゴムを使用することが可能であった。A.B. スクリュー を打ち込むことが不可能な場合は 独自に考案したプレートが有 効であった。【考察】歯牙年齢に応じた本法は有効な方法と思わ れた。

\section{質問} 氏名不詳

顎間ゴムは術直後すぐに用いるのか。

回答神奈川県立こども医療センター 小林 眞司

十分に延長し over correction し，軟部組織も伸展させてから， 顎間ゴムを用いる。

A-6-4. Dentulous Segment Distractionを応用した骨 格性下顎前突症例における術前矯正治療

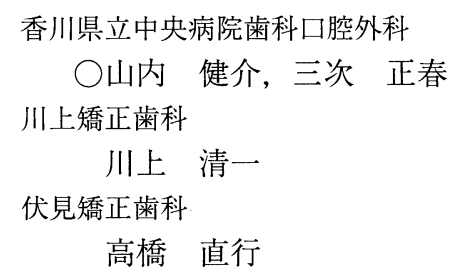

骨格性下顎前突症例においては，しばしば下顎前歯部の舌側傾 斜を呈することがある。顎矯正手術を適用した場合，術前矯正治 療として舌側に傾斜している歯を唇側へとフレアーアウトするこ とが一般的ではあるが, そのような症例においてはsymphysis が薄くなっていることが多く, 唇側の骨吸収による臨床的歯冠長 の増大や根尖部の吸収および顎骨からの逸脱の危険性が挙げられ る。また舌側傾斜に伴って, 叢生や挺出を認める症例においては, 治療期間の長期化が問題点としてあげられる。近年，顎矯正手術 においても，骨延長術が幅広い領域において応用されるようになっ てきている。今回われわれは，上記の問題点を解決する目的で, 下顎前歯部の Segmental Osteotomy を行い，歯を含んた骨片 を形成し，緩徐な力で骨片を唇側へと傾斜させる Dentulous Segment Distraction を行った。症例は男性 2 名で, 両症例と も局所麻酔下において両側下顎側切歯を含んだ Segmental Osteotomy を施行し, 骨片と基底骨をヒンジプレート（BEAR 社）により固定した。術後待機期間をおいて，拡大ネジおよびコ イルスプリングを用いて唇側へと傾斜させていき，目的とされる 位置まで延長を行った。延長終了後に装置を除去し，通常の矯正 装置により保定し骨硬化を計った。本法は，唇側傾斜を行うにあ たって歯に対してほとんど力をかけずに行えることから骨吸収を
はじめとする歯周組織への悪影響を最小限に抑えることができる。 また移動期間も通常の矯正治療に比べはるかに短い期間で行える ことから, 短期間の治療を望む症例においては有用な方法といえ る。これらのことから本法は, 下顎前歯部の舌側傾斜を伴った骨 格性下顎前突症例において, 今後検討されるべき一方法であると 示唆された。

\section{A-6-5. 睡眠時無呼吸を併発した Crouzon 症候群の治療 経験}

\author{
東京歯科大学オーラルメデイシン講座 \\ 東京歯科大学市川総合病院歯科・品犐 \\ 小澤 靖弘, 山根 源之 \\ 東京歯科大学市川総合病院耳鼻咽喉科 \\ 松脇 由典, 中島 庸也 \\ 東京歯科大学市川総合病院脳神経外科 \\ 菅 貞 郎 \\ 渡辺矯正歯科クリニック \\ 渡辺 洋一
}

○外木 守雄, 佐藤一道, 渡 邊 裕,

顎顔面領域に打ける仮骨延長術は, 外科的矯正治療の有効な手 段のひとつとして，その適用範囲が急速に拡大されている。一方 Crouzon 症候群では頭蓋骨縫合, 特に冠状縫合の早期閉鎖に伴 う中顔面の発育不全を呈し, 口腔機能, 審美的障害だけでなく就 寝時の無呼吸が近年重要な問題とされている。今回われわれは睡 眠時無呼吸を併発する Crouzon 症候群患者に対し RED II シス テム（Rigid External Distraction System II ）を応用し, 良好な結果を得たのでその概要を報告する。症例 : 18 歳男性 中 学生時よりいびき, ならびに就寝時の無呼吸を指摘される。1998 年 8 月近隣病院にて睡眠時無呼吸症候群（OSAHS）と診断をさ れ，耳鼻咽喉科にて口蓋垂軟口蓋咽頭形成術ならびに鼻内手術を 受けた。その後, 転居のため継続加療を希望し 1999 年 7 月 27 日 当院紹介来院した。経過 : Polysomnograhy（PSG）検査にて AHI 24.4, Lowest SpO2 74\%の中等度の OSAHS を認めた。 また顔貌ならびに顔面骨形態よりCrouzon 症候群と診断した。 治療方針として OSAHS, 鼻腔容積の拡大, 顔貌, 咬合咀嚼機能 の改善を目的に Le fort III骨切り術による中顔面骨の前方移動が 必要であると判断し, 必要移動量は約 $15 \mathrm{~mm}$ と大きいことから RED II システムによる骨延長術を選択した。術前矯正治療を開 始するとともに体重減量指導と Nasal-CPAP と Oral appliance を併用し OSAHS の改善をはかった。2002 年 10 月 21 日全 身麻酔科にLe fort III骨切り術を行い RED IIによる骨延長を 行った。本システムは 3 次元的に骨延長の方向を調整できるシス テムであり, 本例においても約 1 か月の仮骨延長を行い良好な顔 貌形態，咬合の改善が得られ, OSAHSも軽減した。 


\section{A-7-1. 腓骨により再建した下顎の垂直的仮骨延長}

名古屋大学大学院医学系研究科頭頸部 · 感覚器外科学講座

○間瀬 純治, 日比 英晴, 水野 裕和, 惣城 一美, 坂井 謙介, 伊藤 優子, 大隅 省, 猟山大, 服部宇, 光藤 健司, 畠 賢一郎, 上田 実 中津川市民病院歯科口腔外科

澤木 佳弘

腫瘍などに起因する下顎骨区域欠損に対しては, 腓骨移植によ る再建が有効とされ, さらにインプラントによる機能回復が検討 されるが, 骨の高さが不十分なことが問題になる。その解決に， 移植腓骨における垂直的仮骨延長法が有効であった。その概要を 報告した。症例は 53 歳と 71 歳の男性で, 悪性腫瘍にて下顎骨区 域切除と同時に遊離腓骨皮弁移植による下顎再建が施行されてい た。それぞれ再建後 1 年 5 か月, 1 年 1 か月にて骨切り, 延長装 置（Martin 社 MOD 下顎骨ディストラクタートラック型）の装 着をし， 1 週間の待機期間の後，15 日間で $11.0 \mathrm{~mm}$ と 19 日間で $12.5 \mathrm{~mm}$ の垂直延長をした。延長終了後 11 週間と 23 週間の保定 期間を設けた後，延長装置の撤去と同時にインプラントを埋入し た。移動骨片の断端は延長直後には鋭縁だったが，保定期間終了 時には骨のリモデリングにより移行的になっていた。症例 1 では 仮骨が形成されていたが，まだ十分な骨化は認められなかったた め, 症例 2 では保定期間を長くした。以上 2 例とも, 腓骨のまま では $10 \mathrm{~mm}$ のインプラントの埋入も困難であったが, 垂直的仮 骨延長により $15 \mathrm{~mm}$ 以上のインプラントの埋入が可能となった。 以上より垂直的仮骨延長は移植骨においてもインプラント前処置 として有用であった。

質問北海道大 · 大学院 - 補緅 大 畑 昇

インプラントの植立位置は, 補綴を担当する歯科医との連携の もとに決定されるのでしょうか。

回答 名古屋大 $\cdot$ 大学院 - 頭頸部感覚器外科 日比 英晴

本来であれば先に人工歯の位置を決定し, サージェルガイドで それを反映させます。症例では再建された下顎の形態が十分に適 切であるとはいえず，インプラントの埋入位置に制限が生じまし た。

質問 九州歯大 - 口外 1 福田 仁一

1. 骨延長するまでの期間はどれくらいが適当か。

2. 3 段階の延長スピードを用いた根拠は。

回答 名古屋大 · 大学院 - 頭頸部感覚器外科 間瀬 純治

1. 移植された腓骨が生着し，さらにリモデリングが X 線的 に認められるまでの期間が必要と考えます。

2. 様子を見ながら慎重に延長したためです。
A-7-2. われわれの施設での上顎歯列弓への前後・側方 的な歯槽部仮骨延長法の経験

\author{
福岡歯科大学顎顔面外科学講座口腔腫瘍学分野 \\ ○向坊 重広 \\ 福岡歯科大学口腔顎顔面外科学講座口腔外科学分野 \\ 下田 恒久，泉 喜和子，田中 勝昭， \\ 本田武司 \\ しもだ矯正歯科クリニック \\ 下田哲也 \\ 福岡歯科大学成長発達学講座矯正歯科 \\ 久永 豊, 石川 博之 \\ 福岡歯科大学咬合修復学講座インプラント科 \\ 城戸 寛史，松浦 正朗
}

【はじめに】従来，成人における上顎の歯槽形態の不調和，萎縮 症例では，歯牙への側方拡大を計る顎矯正力が選択される事が多 い。これらの症例では, 後戻りや治療期間も長く, 固定源となっ た歯牙の煩側傾斜や歯槽からの歯根逸脱などを呈しやすく，歯槽 形態に調和した歯軸傾斜が得られているとはいい難い。また，イ ンプラント補綴における前後，側方被蓋の不調和が著しい場合に は, 過度もしくは過不足のオンレーグラフトにより, 粘膜の裂開 やフィクスチャー埋入に困難を来してしまう症例に遭遇したりす る。【症例および結果】われわれの施設では，これらの症例に対 して患者の同意が得られた場合に，仮骨延長法の概念に基づき， 治療前に側方的および前後的な上顎骨切りを併用し，顎骨に固定 源を求めた急速拡大装置（Bony anchored orthopedics）や歯 牙に固定源を求めた急速拡大装置 (Teeth anchored orthopedics）を選択することで治療の簡素化，スピード化を計っている。 われわれの経験した症例は，既に上顎の側方拡大 7 例および前方 拡大 3 例を数える。その内訳は, 顎骨固定源 7 例，歯牙固定源 4 例である。しかし，これらの手法が臨床において根付くためには, 整理すべき問題や患者に配慮する点も少なくない。【結論】今回， われわれは症例に若干の考察を加えることで同手技における利点 および注意すべき点などについて検討した。

\section{A-7-3． 顎関節症を伴った小下顎症に対し PCR 予防目的} に骨延長術を行った 1 例

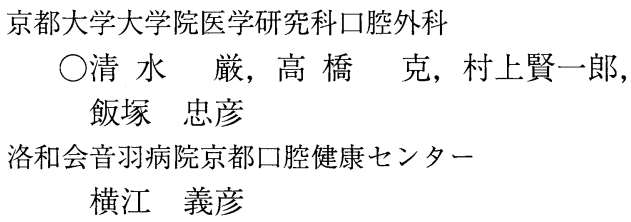

○清 水 厳, 高 橋 克, 村上賢一郎, 飯塚 忠彦 洛和会音羽病院京都口腔健康センター 横江 義彦

外科的矯正術後の進行性下顎頭吸収 Progressive Condylar Resorption（PCR）は, 従来より問題とされる合併症の一つで ある。Hoppenreijs etc.の報告によると，その発現頻度は 6 20\%と高く，20３0 代の女性で，前方移動量の大きい，顎関節症 状を伴う小下顎症に好発すると言われています。今回われわれは 
顎関節症を伴った著明な小下顎症に対して, PCR の予防の為に オクルーザルスプリントを併用しながら, 両側下顎骨延長術を行 い, 咬合機能と審美性の両面に改善の得られた 1 例を経験したの で, その症例の概要について報告する。症例 : 27 歳女性。咀嚼障 害を主訴に来科。下顎の著しい後退を認め, overjet $14 \mathrm{~mm}$, overbite $2 \mathrm{~mm}$, Facial Angle 69.0, Mandibular Plane 59.5, SNA 83.5, SNB 68.2 で小下顎症と診断した。両側顎関節に非 復位性関節円板前方転位と右側顎関節に下顎頭の変形を認めた。 CT データからレーザー粉体焼結モデルを作成し, 手術シュミレー ションを行った後, 全麻下にて両側第 2 大臼歯遠心部から下顎角 部にかけて骨切りを行い,メディコン社製口腔内骨延長装置を装 着した。 1 週間の待機期間の後, オクルーザルスプリントを装着 し，スプリントを調整を行いながら，骨延長を行った。延長量は $14 \mathrm{~mm}$, 延長速度は $0.8 \mathrm{~mm} /$ day であった。延長終了後 30 日で 装置除去, 更に延長部の骨新生を認めた後に上顎 Le Fort I 型 骨切りとオトガイ形成を行った。現在, 骨延長後 11 か月経過し, 顎関節症状の悪化, PCR も認めず良好な咬合状態が得られてい る。

\section{質問} 九州歯大 1 口外 福田 仁一

術前矯正中に顎関節部の症状悪化や, 骨変形は起きなかったの ですか。

回答 京都大. 大学院 - 口外 清 水 厳

従来より顎関節症状を呈していましたが, 術前矯正時は, 特に 顎関節部の症状悪化や, 下顎頭の骨変形は認めていませんでした。

\section{A-7-4. Le Fort I 型骨切り術の骨固定に吸収性ミニプ レートを使用した症例の術後安定性について}

新潟大学大学院医歯学総合研究科口腔生命科学専攻 顎顔面再建学講座組織再建口腔外科学分野 ○加納 浩之, 小林 正治, 本間 克彦, 泉 直也, 加藤 健介, 齊藤 力

【目的】上下顎移動術における骨接合にチタン製のミニプレート が用いられるようになり, 術後安定性については良好な結果が報 告されているが, 生体内での金属イオンの溶出やプレート除去手 術に伴う患者負担の増加などの問題点が指摘されている。近年, 吸収性骨接合材が臨床に広く応用されているが, その強度にやや 難点があるといわれている。今回，われわれは上下顎移動術時の 上顎の骨接合に吸収性ミニプレートを併用した症例の術後安定性 について検討したので報告する。【対象および方法】対象は, 2000 年 1 月から 2002 年 8 月までに当科において上下顎移動術 (上顎：Le Fort I 型骨切り術, 下顎：両側下顎枝矢状分割法) を施行した顎変形症患者のうち, 上顎骨の接合に4箇所ともチ夕 ン製ミニプレートを使用した 22 名（以下，チタン群）と吸収性 ミニプレートを左右梨状口側縁部の 2 箇所に併用した 14 名（以 下, 吸収群) の計 36 名である。術前と術直後ならびに術後 6 か 月以上経過時に撮影した側面頭部 X 線規格写真における上下顎 骨計測点の二次元座標值を, デジタイザーを用いてコンピュータ
に入力し, $\mathrm{S}$ 点を原点として $\mathrm{FH}$ 平面に平行な直線を $\mathrm{X}$ 軸, $\mathrm{FH}$ 平面に直行する直線を $\mathrm{Y}$ 軸として, 手術時移動量と術後変化量 を算出した。【結果】ANSにおける上顎骨の手術時平均移動量は, チタン群が前方に $0.9 \pm 1.9 \mathrm{~mm}$, 上方に $0.2 \pm 1.2 \mathrm{~mm}$, 吸収群が 前方に $3.2 \pm 2.1 \mathrm{~mm}$, 下方に $0.1 \pm 2.6 \mathrm{~mm}$ であった。術後変化量 の平均は, チタン群が前方に $0.1 \pm 1.0 \mathrm{~mm}$, 上方に $0.2 \pm 0.9 \mathrm{~mm}$, 吸収群が後方に $0.02 \pm 0.9 \mathrm{~mm}$, 上方に $0.2 \pm 0.9 \mathrm{~mm}$ であり, 両 群とも術後の変化量は $1 \mathrm{~mm}$ 以内と安定していた。【まとめ】上 下顎移動術時の上顎の骨固定に吸収性ミニプレートを併用しても, 術後の上顎骨の安定性は, チタンプレート使用時と変わらないこ とが示唆された。

質問福岡歯大・腔・顎顔面外科 宇治 寿隆 骨片移動が大きかったり，偏位症例の場合にプレートのベンディ ングの面で吸収性プレートでも充分に適合固定できるとお考えで しょうか。

回答 新潟大 · 大学院 - 口腔再建外科 加納 浩之 骨切り部の差が大きく, 屈曲が難しい場合は骨の断端を丸めて 移行的にすることで対処しています。

質問 釧路労災病院・歯口外 藤盛 真樹

1. 吸収群のチタンプレートはとるのか。

2. 2 群で切開線が違うが，何か意味があるのか。

回答新潟大 · 大学院・ 口腔再建外科 加納 浩之

1. 術後安定性の点より, 現在はチタン製ミニプレートを併用 しています。安定性等で支障がなければ, 将来的には吸収性ミニ プレートのみへの移行も検討しています。

2. 吸収性プレートを併用しはじめた時期に, 骨の分割法を含 めた術式の変更を行ったためで, 骨接合法により切開線を変えて いるのではありません。

\section{A-7-5. 上顎単独手術症例の術後安定性の検討}

福岡歯科大学口腔顎顔面外科学講座口腔外科学分野 泉 喜和子, 下田 恒久, 田中 勝昭, 本田 武司

福岡歯科大学口腔顎顔面外科学講座口腔腫瘍学分野 世良仁, 向坊 重広, 大関 悟

【緒言】本学付属病院では, 上下顎移動術が 91 年度以降の顎変 形症手術の $70 \%$ を占めていたが, 手術手技や麻酔技術の向上と, 患者の体力的な負担を考慮し, 診断を詳細に行い術式の単純化に 努めている。特にLe Fort I 型骨切り術においては下行口蓋動 脈, 翼状突起の処理により, 骨片の移動の自由度を得たことで, 上顎単独手術症例の増加を認めている。そこで今回, 上顎単独移 動の術後安定性を中心に臨床検討した。【対象と方法】対象は平 成 12 年 4 月から平成 15 年 3 月までの 3 年間に当科において, 同 一術者によるLe Fort I 型骨切り術 (Genioplastyの併用を含 む）を施行した患者 11 名（男性 1 名, 女性 10 名）とした。評価 法として術前, 術直後, 術後 3 か月の頭部 X 線規格写真, 顔貌 写真と模型を用いた。上顎の移動距離と方向は術前後の模型を用 
い, 術後の安定性は側面頭部 X 線規格写真を用い, 各計測点の 変化を計測した。【結果とまとめ】臨床診断として, 上顎前突症 7 症例, 上顎歯槽前突症 3 例, 上顎後退症 1 例であった。術式は全 症例に high level な Le Fort I 型骨切り術を行い, 上顎骨片は ミニプレートにて固定した。上顎後方移動距離の最大值は $4 \mathrm{~mm}$, 上方移動では最大值 $7 \mathrm{~mm}$ で, 上顎移動は予定通り行われ, 術直 後と術後 3 か月のセファロ分析において, 上顎の位置に変化はみ られず, 術後安定性を得ていた。また, 上顎前突症では, 変形性 顎関節症の既往がある症例が多く, 上顎単独手術では, 適合した 下顎頭に過剩な負荷を与えない配慮が可能となった。

\section{A-8-1. 下顎枝矢状分割法による下顎後方移動後の顎顔 面形態と舌縮小術の適応について}

\author{
奈良県立医科大学口腔外科学講座 \\ ○菅 敏 正, 川上 正良, 山本一彦, \\ 慰斗 利光, 藤本 昌紀, 大儀 和彦, \\ 桐田 忠昭
}

【目的】顎矯正手術によって下顎骨を後方移動させると， 口腔内 容積に占める舌の大きさが増加し, 術後の後戻りをおこしやすい と考えられてきた。舌の大きさは歯の位置異常や開咬, 下顎前突 などの不正咬合と関連しているとされ, 舌縮小術の効果を述べた 報告がある。本研究では, 下顎骨後方移動後の顎顔面形態の変化 に対して舌縮小術がどのような影響を及ぼすか検討した。【方 法】対象は下顎枝矢状分割術により下顎骨を後方移動させ， semirigid fixationを行った骨格性下顎前突症患者 40 名である。 顎顔面の先天異常あるいは上下顎移動術を行った症例は除外した。 このうち術前診査により相対的な macroglossia と診断した 21 名に対し, Keyhole 型 (Egyedi-Obwegeser 法) もしくはW 型（Mixter 法）の舌縮小術を同時に施行した。術前, 術後 1 か 月, 術後 1 年に撮影した側面頭部 X 線規格写真を用い, 上下顎 関係および舌・上気道形態, 舌骨の位置について計測を行い, 舌 縮小術を行わなかった群と比較検討した。【結果】下顎骨の後方 移動により, 術後 1 か月では舌骨の後下方への移動が両群とも認 められた。術後 1 年では, 舌骨の位置はほぼ術前の位置にもどっ たが, 舌根部の気道前後径の減少が認められた。舌縮小術を行っ た群では, 舌根部の気道前後径の減少が軽度であった。術後の上 下顎関係ならびに overjet, overbiteの変化については, 両群に 有意差は認められなかった。【結論】下顎骨後方移動後の舌およ び舌骨の位置変化によって, 顎顔面形態は術後の新しい環境に順 応するため, 舌縮小術の有用性は低いことが示唆された。

質問鶴見大・歯・1口外 石井 宏昭

1. 舌縮小術による術後の合併症はありますか。

2. 縮小術を行った群と施行しなかった群で, 上下顎前歯歯軸 傾斜の検討はされていますか。

回答奈良医大 - 口外 山本一彦

1. Egyedl-Obwegeser 法では, 術後舌の知覚低下を認めた 症例があったが, Mixter 法に変更してからはみられなかった。
2. 前歯部歯軸の傾斜による代償はない様に思われます。

\section{A-8-2. 骨格性下顎前突症患者に対する上下顎移動術の 術後安定性}

九州歯科大学口腔外科学第 1 講座

○吉岡 泉, 冨永 和宏, 福田 仁一

【目的】骨格性下顎前突症は我が国において外科的矯正治療の対 象となる顎変形症の中で圧倒的に大きな割合を占める。骨格性下 顎前突症のうち, 上顎骨の前後的垂直的位置異常あるいは上顎咬 合平面の前後的傾斜や左右的傾斜に問題がある症例について当科 では上下顎移動術を行っている。今回われわれは上下顎移動術を 施行した骨格性下顎前突症患者について術後の安定性を X 線学 的に評価した。【方法】1995 年以降当科で上下顎移動術を行った 骨格性下顎前突症のうち, 非刘称および開咬症を伴うものは除外 し, 上顎に対して Le Fort I 型骨切り術を, 下顎に対して両側 下顎枝矢状分割術を行ったものに対象を限定し, 術後 2 年以上経 過した 15 症例について検討した。資料には手術直前, 手術直後, 術後 3 か月, 術後 6 か月, 術後 1 年, 術後 2 年時に撮影した側面 頭部 X 線規格写真を用い, 代表的計測点の XY 座標值の変化を 計測した。【結果および考察】Point B と Pog は術後 3 か月まで 経時的に前下方へ位置変化する傾向にあったが, その後は安定す る傾向にあった。Point A は術後に後方へ位置変化する傾向に あったが, その変化量は Point B P Pog の位置変化量に比べて 少なく, 安定していた。

質問近畿大·医 ·奈良病院 - 歯口外 古田 治彦

下顎後方移動術単独症例との比較で, 術後安定性に違いが認め られるか否かについて御教示下さい。

回答杂州歯大 1 口外吉 岡 泉

下顎後方移動術のみの症例の方が, 安定性が高いという印象で す。

\section{A-8-3. Le fort I 型骨切り術における術後の安定性} 一チタンプレートとポリ-L-乳酸プレートの比較一

神戸市立中央市民病院歯科口腔外科

○片岡 洋平, 古谷 昌裕, 竹信 俊彦

【緒言】顎変形症手術における固定には, 従来チタンプレートが 用いられてきた。近年, 開発されたポリーL-乳酸 (以下, PLLA) プレートは異物反応も少なく, 摘出手術が不必要なことから, 当 科においても 1998 年より使用を開始した。しかし, 操作性, と りわけ屈曲性に限界があり鋭利な角度をつけることは難しい。そ れゆえ当科では症例に応じてチタンと PLLA プレートを選択し 使用している。大きな前後移動を伴い, 上顎骨前壁のステップが 大きく直角に近いプレートの屈曲を要するものはチタンプレート による固定, それ以外で大きな屈曲が必要のない症例については PLLA プレートを用いている。今回, われわれは Le Fort I 型 骨切り術において PLLA, チタンプレートを用いた症例の術後 
安定性について比較, 検討したので報告する。【材料と方法】 Le fort I 型骨切り術を施術し, 術後 1 年以上経過した 40 症例 (PLLA 群 23 例とチタン群 17 例) について分析を行った。分析 は術前, 術直後, 術後 1 年, 術後 2 年の側貌セファロ X 線規格 写真を sella 基準として FHに対して平行線と垂線を引き ANS と PNS の X 軸と Y 軸の移動量を絶対值で計測した。【結 果および報告】手術による移動量は, 前述の選択基準の如くチ夕 ン群の方が大きかった。ANS, PNS の X 軸と Y 軸における術 直後から術後 1 年, 術後 1 年から 2 年の移動量の差はともに 1 ミ リ以下であり, PLLA 群とチタン群の術後安定性については有 意な差は認めなかった。PLLA 群とチタン群の手術による移動 量に有意の差があることから, 比較は困難であるが, 症例を選択 すればPLLA プレートを使用してもチタンプレートと同様の術 後安定性を得ることが可能であると思われた

\section{A-8-4. 非対称性下顎前突症に適応した顎矯正手術の違 いが術後にあたえる影響}

\author{
奥羽大学歯学部歯科矯正学講座 \\ ○松山 仁昭, 黒田 栄子, 小川 秀樹, \\ 福井 和徳, 水室 利彦
}

【目的】下顎単独骨切り術と上下顎骨切り術を適用した非対称性 下顎前突症の術後安定性について検討すること。

【資料および方法】奥羽大学歯学部附属病院において 1992 年〜 2002 年に非対称性下顎前突症と診断され, 下顎単独移動術 （SSRO）を施行した 10 症例（平均 $\mathrm{ANB}-2.2^{\circ}$, 男子 2 名, 女 子 8 名, 手術時平均年齢 22 歳 5 力月, 以下 one-jaw 群), 上下 顎移動術（Le fort I $+\mathrm{SSRO}$ ) を施行した 10 症例（平均 ANB $-5.9^{\circ}$, 男子 4 名, 女子 6 名, 手術時平均年齢 21 歳 4 か月, 以 下 two-jaw 群) を対象とした。骨片固定法は miniplateによる semirigid fixationを行った。術直前 $(\mathrm{T} 0)$, 術直後 $(\mathrm{T} 1)$, 術 後 6 か月（T2）, 術後 1 年（T3）の各時点で採得した正面, 側面, 軸位頭部 X 線規格写真を分析資料とした。各群の手術による変 化を unpaired t-test, 手術後各時点での計測值を分散分析によ り比較し, 手術時移動量に対する術後変化量の相関を求めた。

【結果】1）手術による変化: 正面頭部 X 線規格写真のオトガイ 部最下点（以下, $\mathrm{Me}(\mathrm{F})$ ) の変化量では, one-jaw 群は twojaw 群に比べ大きかった $(\mathrm{p}<0.05)$ 。軸位頭部 X 線規格写真の 左右棘孔中点を結んだ線分の垂直二等分線と左右下顎頭長軸とな す角 (以下, 下顎頭長軸角) では, one-jaw 群は two-jaw 群に 比べ大きかった $(\mathrm{p}<0.05)$ 。2) 術後の安定性 : One-jaw 群 $\mathrm{Me}(\mathrm{F})$ では, 術直後から 6 か月までの変化が大きく, $\mathrm{T} 1$ と $\mathrm{T} 2$ 間， $\mathrm{T} 1$ と $\mathrm{T} 3$ 間に有意な差が認められた $(\mathrm{p}<0.05)$ 。3）手術に よる変化と術後変化の比較: One-jaw 群における手術時の偏位 側下顎頭長軸角の変化量と $\mathrm{Me}(\mathrm{F})$ の術直後から術後 6 か月まで の変化量に相関を認めた $(\mathrm{R}=-0.79, \mathrm{p}<0.01)$ 。

【まとめ】 One-jaw 群では手術時の $\mathrm{Me}(\mathrm{F})$ が大きく変化し, 内側骨片が非偏位側に大きく移動した。また, One-jaw 群の偏
位側下顎頭長軸角が増大した。内側骨片の外側への移動により， 骨接合部におけるはね上げ量が大きくなったものと考えられる。 下顎単独移動術と上下顎移動術では上下顎移動術が安定性を得ら れやすく，下顎の後戻りが軽減すると考えられた。

\section{B-1-1. skeletal Class II 症例における生体吸収性骨接 合性システムの術後評価}

\author{
山形大学医学部歯科口腔外科学講座 \\ ○小関 清子, 高橋 晃治, 吉澤 信夫 \\ 北海道医療大学歯科口腔外科学第 1 講座 \\ 柴田 考典 \\ 山形県開業 \\ 中村 晴哉
}

【緒言】近年, 生体内吸収性ポリ-L-乳酸 (PLLA) 製骨接合シ ステムが開発され，顎矯正手術における安全性や有用性に関する 報告も散見されるようになった。しかし，PLLA 製骨接合シス テムを応用した skeletal Class II 症例の術後安定性を調査した 報告は認められない。そこでわれわれは，下顎骨前方移動症例に 対し PLLA 製ネジを用いて近・遠位骨片の固定を行った症例の 術後経過に関する調査を行い若干の知見を得たので報告した。 【対象・方法】対象は skeletal Class II と診断し, 当科にて下 顎枝矢状分割法による下顎骨前方移動術を適応し PLLA 製スク リュウ（FIXSORB-MX）にて骨片固定を行った 3 症例である。 なお, 従来より応用しているチタン・ミニプレートにて骨片固定 を行った 3 症例も比較対照とした。調査項目は, 各症例の術直前, 術後 $1,3,6$ か月目に撮影した頭部 X 線規格写真の透写図を用い て, $\mathrm{FH}$ 平面および $\mathrm{FH}$ 平面の垂線に投影した B 点, L1, Pogonion, Mentonの水平的変化量と垂直的変化量とした。そして, 術後 1 か月目を基準として 3,6 か月目の変化量を調査した。【結 果】PLLA 製スクリュウを応用した症例における各計測時期の 水平的, 垂直的位置変化はいずれも $1 \mathrm{~mm}$ 以内であり, チタン. ミニプレートを応用した症例においても同様の変化であった。 【考察】生体埋入後 3 か月間は当初の約 $80 \%$ の強度を保つとされ る PLLA 製骨接合システムの skeletal Class II 症例に対する応 用において, この間の術後安定性では問題となる症例は経験しな かった。

質問 三次矯正歯科クリニック 鶴田 仁史

1. 移動量の大小によって差がでてくると思われますか。

2. 術後変化には, 下顎頭の問題も含まれていることを考慮し て計測点を設定されていますか。
回答
山形大·医 ·歯口外 大関 清子

1. 症例数が少ないですが, 今回の症例の最大移動量は $7 \mathrm{~mm}$ で, 術後安定性では問題となる症例は経験しませんでした。

また, 移動量の多い症例では上顎骨切り術を併用して対応して おります。

2. 症例数が少ないこともあり, 評価していませんが, 今後長 期的に経過観察を行い, 顎関節の吸収に関しても評価していきた 